\title{
Microglia and Astrocytes in Alzheimer's Disease in the Context of the Aberrant Copper Homeostasis Hypothesis
}

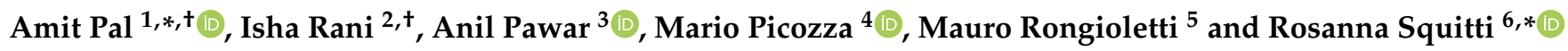 \\ 1 Department of Biochemistry, AIIMS, Kalyani 741245, West Bengal, India \\ 2 Department of Biochemistry, Maharishi Markandeshwar Institute of Medical Sciences and \\ Research (MMIMSR), Maharishi Markandeshwar University (MMU), Mullana, Ambala 133207, Haryana, \\ India; singlaisha8@gmail.com \\ 3 Department of Zoology, DAV University, Jalandhar 144012, Punjab, India; sumanil27@yahoo.co.in \\ 4 Neuroimmunology Unit, IRCSS Fondazione Santa Lucia, 00143 Rome, Italy; m.picozza@hsantalucia.it \\ 5 Department of Laboratory Medicine, Research and Development Division, San Giovanni Calibita \\ Fatebenefratelli Hospital, Isola Tiberina, 00186 Rome, Italy; maurociroantonio.rongioletti@fbf-isola.it \\ 6 Molecular Markers Laboratory, IRCCS Istituto Centro San Giovanni di Dio Fatebenefratelli, \\ 25125 Brescia, Italy \\ * Correspondence: maximus1134@gmail.com (A.P.); rosanna.squitti@afar.it (R.S.) \\ + Co-first authors.
}

check for

updates

Citation: Pal, A.; Rani, I.; Pawar, A.; Picozza, M.; Rongioletti, M.; Squitti,

R. Microglia and Astrocytes in

Alzheimer's Disease in the Context of the Aberrant Copper Homeostasis Hypothesis. Biomolecules 2021, 11, 1598. https://doi.org/10.3390/ biom 11111598

Academic Editors: Marcus O W. Grimm and Nela Pivac

Received: 5 June 2021

Accepted: 22 October 2021

Published: 28 October 2021

Publisher's Note: MDPI stays neutral with regard to jurisdictional claims in published maps and institutional affiliations.

Copyright: (c) 2021 by the authors. Licensee MDPI, Basel, Switzerland. This article is an open access article distributed under the terms and conditions of the Creative Commons Attribution (CC BY) license (https:// creativecommons.org/licenses/by/ $4.0 /)$.
Abstract: Evidence of copper's (Cu) involvement in Alzheimer's disease (AD) is available, but information on $\mathrm{Cu}$ involvement in microglia and astrocytes during the course of AD has yet to be structurally discussed. This review deals with this matter in an attempt to provide an updated discussion on the role of reactive glia challenged by excess labile $\mathrm{Cu}$ in a wide picture that embraces all the major processes identified as playing a role in toxicity induced by an imbalance of $\mathrm{Cu}$ in AD.

Keywords: astrocyte; microglia; copper; Alzheimer's disease

\section{Introduction}

The pleiotropic pathogenesis of Alzheimer's disease (AD), along with drugs developed in the "inside-out approach," which relied heavily around halting/clearing intracellular aggregates of the hyper phosphorylated tau protein and extracellular plaques of the $\beta$ amyloid (A $\beta$ ) peptide, led to the failure of most clinical trials despite decades of research. Lately, thanks to the rapid development and improvement of imaging technologies and experimental research, attention has been diverted beyond the "classical neuronal death or $\beta$-amyloid cascade hypothesis" to the immediate surroundings around neurons, i.e., nonneuronal cells (glial cells) in neuronal health, aging, and AD (the outside-in approach) [1,2].

Among glial cells, astrocytes have rapidly emerged as cells with an important supporting role in learning and memory consolidation [3], along with protecting the central nervous system (CNS) from metal toxicity [4], including copper $(\mathrm{Cu})$ neurotoxicity [5]. Microglia involvement is also increasingly factored into sporadic AD pathogenesis [6,7]. It has also been postulated that cognitive decline managed by modifiable lifestyle factors is thought to be mediated by the mitigation of aberrant microglia activation in aging and the subsequent suppression of neuroinflammation [8]. Intriguingly, CNS Cu dyshomeostasis hypothesis fits very well in either approach for elucidating the pathogenesis or finding novel drug targets for a specific subgroup of AD patients [9].

In this review, several mechanisms of $\mathrm{Cu}$ toxicity identified as contributing to $\mathrm{AD}$ onset and progression are briefly explained, with a focus on the involvement of microglia and astrocytes in the context of $\mathrm{Cu}$ imbalance playing a part in $\mathrm{AD}$ pathogenesis/development in a subset of $\mathrm{AD}$ patients. 


\section{Microglia and Astrocytes}

\subsection{Microglia and Astrocytes in Health}

Among immune cells, the CNS is primarily populated with microglia, which constitutes slightly less than $10 \%$ of CNS cells. Besides microglia, cells pertaining to other types of mononuclear phagocytes (i.e., CNS-associated macrophages) populate distinct CNS regions-meninges, choroid plexus, and perivascular spaces, from which their nomenclature arise [10] - servicing in barrier functions. Together with microglia and other nonneuronal cells, they contribute to the regionalization of the peculiar immunity, metabolism, and physiology of the CNS. In the steady state, and with the partial exception of choroid plexus macrophages, all of these CNS mononuclear phagocytes are maintained throughout life by local turnover/self-renewal [11]. While the infiltration of blood-borne monocytes and their differentiation into microglia-like cells may take place following inflammatory and disease conditions in experimental animal models and perhaps the human CNS, the in situ slow rate of proliferation provides a major source of microglia. Early migration of their precursors into the developing brain and co-habitation during CNS cell differentiation endow microglia with a well-integrated set of functions, beyond debris scavenging. This contributes to a balanced incorporation of neurons into functional circuits. First, microglia control the number of neurons interfering with both embryonic and adult neurogenesis by actively phagocytosing neuronal precursor cells [12] and by feeding neurons with soluble factors that can either support their viability, such as insulin-like growth factor 1 (IGF1)] [13], or induce cell death, such as nerve growth factor (NGF) [14]. Afterwards, during brain development, microglia prune weak synapses tagged by complement components [15] and the phagocytic receptor triggering receptor expressed on myeloid cells 2 (TREM2) [16], thus limiting excessive redundancy in neural circuits [17].

Astrocytes, also known as astroglia, exhibit a star-shaped morphology with several cellular processes spreading from the soma [18]. Astrocytes, the most numerous cell type in CNS, have an intimate physical association with blood vessels and single, as well as groups of, synapses in the brain. They perform a variety of functions, including axon guidance and synaptic support, regulation of extracellular concentrations of ions, neurotransmission, and control of the blood-brain barrier (BBB) and blood flow. Astrocytic terminal processes or end-feet form a lacework of fine lamellae by completely covering the outer surface of the endothelium. Astrocytic end-feet release various soluble factors, such as glial cell-line neutrophic factor (GDNF), transforming growth factor-beta (TGF- $\beta$ ), basic fibroblast growth factor (bFGF), and angiopoetin-1 (ANG-1), thereby regulating the process of angiogenesis and the formation of endothelial cell-to-cell junctions that preserve the structural and functional integrity of the BBB [19]. It is known that neurons and glia cooperate in the modulation of cognitive functions [20] by controlling synaptic plasticity and neurotransmission. Astrocyte dysfunction has an effect on neurotransmission and may result in different neuropsychiatric disorders, as well as neurodegenerative diseases, including $\mathrm{AD}[1,2]$.

\subsection{Microglia and Astrocytes in Alzheimer's Disease}

Several emerging studies have suggested the involvement of glial cell deregulation as a major contributor of cognitive deficits and neurodegenerative processes seen in AD. Compelling evidence has revealed the biphasic roles of microglia in the pathogenesis of AD. According to previous literature, microglial phenotypes in $\mathrm{AD}$ were defined by the occurrence of specific cell surface molecules and cytokines, such as the classical activation (M1; proinflammatory and cytotoxic) phenotype and the alternative activated (M2; participates in subsiding inflammation) phenotype. Impaired microglial polarization with excessive activation of the M1 phenotype and dysfunction of the M2 phenotype significantly facilitates AD. However, the concept of a microglial phenotype has been recently redefined to correctly explain the complex physiology of microglial cells. In a healthy brain, an exclusive homeostatic molecular and functional signature (M0) [21] is present and is firmly controlled by transforming growth factor $\beta$ (TGF $\beta$ ) signaling [21]. In contrast, microglia transits from 
a homeostatic molecular signature [22] to a chronically inflammatory phenotype [23] over the course of the disease.

Recent single-cell RNA sequencing studies on the human AD brain and on a murine model of AD that expresses five human familial AD mutations (5XFAD) have observed a unique "neurodegenerative" phenotype or disease-associated microglia (DAM). This "neurodegenerative" phenotype is shared by $\mathrm{AD}$, amyotrophic lateral sclerosis, frontotemporal dementia, and aging [24-27]. This "neurodegenerative" phenotype is triggered by the activation of TREM2-APOE signaling, which suppresses the unique homeostatic molecular and functional microglial phenotype (M0) $[25,28]$. DAMs are characterized by a downregulation of key homeostatic genes (e.g., P2ry12, Tmem119, Cx3cr1, Gpr34, Csf1r, Hexb, and Mertk) $[25,26]$ with a concomitant upregulation of selective inflammatory genes, including Spp1, Itgax, Lgals3, Axl, Clec7a, Ccl2, and Apoe [25]. DAMs have been primarily recognized in 5XFAD, and their characteristics have been confirmed in other amyloid- $\beta$ (A $\beta) A D$ mouse models $[24,25,29]$ and tauopathy models $[24,30]$. In 5XFAD and APP/PS1 models of $\mathrm{AD}$, the co-localization of DAM with $\mathrm{A} \beta$ plaques was observed in the cortex $[26,31]$. The analysis of microglia from these AD models deficient in TREM2 revealed the two stages of DAM: Stage 1 (TREM2-independent) and Stage 2 (TREM2-dependent). Based on these recent findings, it was demonstrated that three microglia subtypes, including homeostatic microglia and Stage 1 and Stage 2 DAM, were present in a mouse AD model [26].

In vivo and in vitro studies have proposed several mechanisms for understanding the role of microglial activation in response to neuropathological conditions [32]. During $\mathrm{AD}$ progression, the microglia may interact with $\mathrm{A} \beta$ peptides and neurofibrillary tau tangles (NFTs) through different receptors, including the receptor for advanced glycation end products (RAGEs), G protein-coupled receptors formyl peptide receptor 2, chemokine-like receptor 1 , TLRs $2 / 4$, the CD14 co-receptor, and the $\alpha 6 \beta 1$ integrin [32]. This association, in turn, results in a sequential overactivation of inflammatory mediators, such as inflammatory cytokines, complement components, chemokines, and oxidative stress, which is suggestive of activated microglia as a major source of neuroinflammation during $\mathrm{AD}$ pathogenesis. Murine studies have also indicated that mutation in the TREM2 gene, expressed by microglia in the CNS, interferes with $\mathrm{A} \beta$ clearance and increases tau hyperphosphorylation due to the reduced phagocytic activity of microglia cells $[33,34]$. The role of microglia in tau pathology is highly complex: microglial cells sequester tau for degradation but do it inefficiently and, in turn, release tau that stimulates aggregation in recipient cells [35]. Notably, a recent study found that amyloid plaques associated with hyper phagocytic DAM can also exacerbate the propagation of pathologic tau through extracellular vesicle secretion in a humanized APP mouse model [36]. Moreover, activated microglia can also cause synapse loss, likely via a complement-dependent mechanism and, therefore, also aggravate tau pathology and release inflammatory factors that can damage neurons directly or indirectly by the induction of neurotoxic astrocytes [37]. For instance, the genetic deletion of the complement factors $\mathrm{C} 1 \mathrm{q}$ and complement component 3 (C3) or the microglial complement receptor CR3 decreases the early synapse loss and the number of activated microglia, which, by provoking the induction of phagocytic microglia, is suggestive of complement activation as an early mediator for plaque-associated synapse loss in AD brains [38-40].

Conversely, microglia can also exert a neuroprotective role by generating anti-A $\beta$ antibodies and enhancing the clearance of amyloid plaques and tau seeding. Furthermore, $A \beta$ has been implicated in the microglia free-radical production in response to $A \beta$ [41]. Microglia efficiently take up $A \beta$ aggregates when $A \beta$ forms a complex with lipoproteins, such as low-density lipoprotein (LDL), apolipoprotein $\mathrm{E}$ (apoE), and clusterin/apolipoprotein $\mathrm{J}$ (CLU/apoJ) [42,43]. The interaction between microglia and the $\mathrm{A} \beta /$ amyloid precursor protein (APP) through specific pattern recognition receptors (PRRs), including CD14, CD36, and TLRs, on microglial surfaces activates $A \beta$ clearance by inducing microglial phagocytosis [44]. In addition, lipopolysaccharides (LPSs), inducers of inflammation, have been observed to activate microglia for the potentiation of $A \beta$ degradation [45]. However, 
previous literature has suggested an opposite role for LPSs: exacerbating tau pathology and inhibiting or unaffecting $A \beta$ clearance. This makes the contribution of LPSs in A $\beta$ clearance questionable [46,47]. Additionally, LPSs and other bacterial products, such as E. coli K99 pili protein, have also been detected in AD specimens [48,49]. Notably, LPSs colocalize with $\mathrm{A} \beta_{1-40 / 42}$ in amyloid plaques and around vessels in AD brains [48]. Cathepsin $\mathrm{B}(\mathrm{Cat} \mathrm{B})$, a lysosomal cysteine protease, also participates in microglia-mediated $A \beta$ clearance in the early stages of AD [50]. A recent study has elucidated that TREM2-dependent activation of the DAM phenotype mitigated $A \beta$-induced pathological tau seeding and spread in a mice model of AD [36]; however, the ablation of both TREM2KO and microglia reversed the effect by dramatically increasing tau propagation and spreading around plaques [36].

Recent studies have also shown evidence for the existence of a causal relationship between astrocytes and neurodegeneration. Astrocytes are also known to elicit an effect that may be neuroprotective or deleterious in the AD. Astrocytes can become reactive under certain acute or chronic stressful conditions and correspond to "A1" proinflammatory and "A2" anti-inflammatory, respectively [51]. In vitro and in vivo studies have reported the accumulation of reactive astrocytosis (the A1 phenotype), particularly around amyloid plaques encircling $A \beta$ deposits in AD brains [52]. The activation of astrocytes by $A \beta$ or from damage or injury, or activated microglia, can trigger the overproduction of inflammatory cytokines, including interlukin-1 (IL-1), C1q, and TNF- $\alpha$, which results in the generation of oxidative stress and, subsequently, promotes neurodegenerative processes in AD [53].

The mechanisms related to the interaction of astrocytes with A $\beta$ are not clearly known; however, astrocytes are known to express a variety of receptors, such as the RAGE, lipoprotein receptor-related proteins (LRPs), membrane-associated proteoglycans, and scavenger receptor-like receptors, which can identify and bind to A $\beta$ (reviewed in Reference [54]). Moreover, $A \beta$ aggregates can also induce the production of chemotactic molecules (monocyte chemoattractant protein-1 (MCP-1)), which favor the recruitment of astrocytes to the site of injury [55]. According to previous research, $A \beta$ aggregates can also support the inflammatory processes induced by astrocytes [56]. A $\beta$ stimulates NF- $\kappa$ B and complement signaling in astrocytes, which may induce the synthesis of inflammatory mediators by astrocytes and impair synaptic density and dendritic morphology [57,58], responsible for neurodegenerative changes in AD. Astrocytes cause nitric oxide (NO)-mediated neurotoxicity by increasing the expression of inducible nitric oxide synthase (iNOS) and contribute to sustained neuroinflammation [59]. Additionally, the astrocyte A1 phenotype is known to cause nerve damage by enhancing the classical C3 factor [53]. Interestingly, these could also drive the production of $A \beta$ under certain inflammatory conditions, such as TGF- $\beta 1$ alone [60], or IFN- $\gamma$ in combination with TNF- $\alpha$ [61,62] or IL-1 $\beta$ [62].

Astrocytes can also engulf partly digested $A \beta$, which lead to astrocytic defects and neuronal apoptosis [63]. There is also evidence that reactive astrocytes display an increase in the level of APP, $\beta$-secretase (BACE1), and $\gamma$-secretase, which assemble the essential machinery accountable for forming $\mathrm{A} \beta$ peptides and their aggregates $[61,64]$. Complicating the matter, they also blunt the plaque buildup by helping in clearing the $\mathrm{A} \beta$ peptide, as shown by in vitro and in situ studies [55]. Beyond the role of astrocytes in A $\beta$ aggregation, the phenotype A2 is also involved in the clearance of $A \beta$, which is indicative of the neuroprotective role in the neurodegenerative processes of AD [55]. In fact, AD mouse models demonstrate reactive astrogliosis even before the appearance of $A \beta$ deposits and suggesting it as a very early event [65]. Strikingly, these cells are also closely involved in $A \beta$ catabolism [64]. Human studies involving prodromal AD subjects corroborate findings in animal studies, wherein monoamine oxidase activity was significantly higher and indicated astrogliosis [66]. On a similar line but an extended approach, the local ablation of astrocytes resulted in neurodegeneration in specific regions of animal models, which may be partly due to a decrease in the neuroprotective activity of astrocytes and increased excitotoxicity [67].

It is believed that astrocyte-induced $A \beta$ clearance may be stimulated by an increment in the expression of proteases, such as neprilysin, insulin-degrading enzyme, endothelin- 
converting enzyme (ECE), and metalloproteases [68-71]. There are also several complementary mechanisms related to the secretion of extracellular chaperones by astrocytes, including ApoE, apolipoprotein J (Apo J)/clusterin, $\alpha 2$-macroglobulin $(\alpha 2-\mathrm{M})$, and $\alpha 1-21$ antichymotrypsin (ACT), which participate in A $\beta$ clearance across the BBB $[54,72-74]$. The A2 phenotype displays protective features by upregulating several neurotrophic factors, such as S100 calcium-binding protein A10 (S100A10) and brain-derived neurotrophic factor $[51,53]$. Interestingly, astrocytes form a structural protective barrier between amyloid deposits and neurons, which preserve neural tissue and restrict the deleterious effects of inflammation in $\mathrm{AD}$ cases [55]. Beyond their role in removing or degrading $\mathrm{A} \beta$, astrocytes can also release many trophic factors that may exert a biphasic effect in AD. For example, astrocytes maintain neuronal function and cognitive performance by secreting GDNF in aged rats [75], whereas overexpression of NGF can cause neurotoxicity, as well as damage to hippocampal neurons [76]. The crosstalk between microglia and astrocytes in the neuroinflammatory process is increasingly gaining attention in the field of glial research. In fact, the shift to the A1 phenotype is regulated by microglial activation and the coexistence of both $\mathrm{A} 1$ astrocytes, and activated inflammatory microglia has been seen in the prefrontal cortex of AD patients [77].

Moreover, in vitro experimental studies have observed that glial cells can be activated by metals, a hallmark of neuroinflammation that facilitates APP expression and insoluble $A \beta$ formation [78]. In this context, the next section of this review highlights a synopsis of the chemical, biological, and toxicological aspects of $\mathrm{Cu}$ and emphasizes oxidative stress as a crucial event in facilitating its toxicity in $\mathrm{AD}$ [79].

\section{Main Processes of Oxidative Stress in AD: The Linkage with $\mathrm{Cu}$ Imbalance}

Exposure to $\mathrm{Cu}$, particularly the divalent form, has been proposed to augment the risk of an onset of $\mathrm{AD}$ [80]. Coordination chemistry along with meta-analysis and with epidemiological and genetic studies $[79,81]$ show involvement of $\mathrm{Cu}$ and non-ceruloplasmin $\mathrm{Cu}$ (also known as 'free' $\mathrm{Cu}$ ) [82], a component of serum $\mathrm{Cu}$ not bound to proteins and specifically not bound to ceruloplasmin, from which its name is derived, in $\mathrm{AD}$, as posited by the $\mathrm{Cu}-\mathrm{AD}$ hypothesis (reviewed in Reference [83]). This hypothesis theorizes that an age-driven $\mathrm{Cu}$ imbalance results in a gradual shift from protein-bound metal ion pools to pools of loosely bound metal ions that drives a bloodstream non-ceruloplasmin Cu excess in $\mathrm{AD}$ [84].

This hypothesis stems from the increasing number of experimental, meta-analysis, and multifactorial studies that have delineated that chronic exposure to $\mathrm{Cu}$ and its imbalance is linked to accelerated cognitive decline and AD pathology in the human brain [79,85-88]. As evidenced by seminal dietary experiments [89] and confirmed in AD transgenic models [90-92], a paradigm of 9-12 months of exposure to $1.3 \mathrm{ppm} \mathrm{Cu}$ in drinking water unraveled the mechanism of $\mathrm{Cu}$ toxicity linked to $\mathrm{AD}$ pathology. Chronic $\mathrm{Cu}$ exposure (1.3 ppm Cu in drinking water) after 9 months interferes with the LRP1-mediated clearance of $A \beta$ alterations in cortical vasculature by altering microRNA dynamics, which indicates an involvement of $\mathrm{Cu}$ exposure in brain vascular damage by augmenting vascular $\mathrm{A} \beta$ accumulation and, thereby, increasing the risk for developing cognitive decline and AD [90]. Preclinical studies clearly show how chronic $\mathrm{Cu}$ exposure increases non-ceruloplasmin $\mathrm{Cu}$ in plasma and in brain capillaries [91,93], mimicking non-ceruloplasmin $\mathrm{Cu}$ excess noted in AD patients [94] and, particularly, in a subset of AD patients [83], which is typified by non-ceruloplasmin $\mathrm{Cu}$ levels higher than $1.6 \mu \mathrm{mol} / \mathrm{L}$ and susceptibility to $\mathrm{Cu}$ disturbances on a genetic basis $[81,95]$. Notably, non-ceruloplasmin $\mathrm{Cu}$ crosses the BBB, which is exemplified by Wilson disease, the paradigmatic disorder of $\mathrm{Cu}$ accumulation on a monogenic basis. In $\mathrm{AD}$, as well, its excess can lead to impairment in the hippocampal synaptic structure and spatial memory, as shown in preclinical studies and confirmed in AD brain specimens $[90,96,97]$. 
In the next sub-sections, we will discuss in detail how $\mathrm{Cu}$ can directly bind with $\mathrm{A} \beta$ and promote the accumulation and oligomerization of $\mathrm{A} \beta$, which aggravates reactive oxygen species (ROS) generation, responsible for oxidative neuronal damage [98].

\subsection{Oxidative Stress and the Loss of Functional Cu in a Protein-Bound Pool}

In this section, we refer to functional $\mathrm{Cu}$ in a protein-bound pool as $\mathrm{Cu}$ that is structurally bound in proteins/enzymes that have a well-defined function in the cell/tissue, particularly those that play a role in the brain. This is opposite to the loosely bound, exchangeable $\mathrm{Cu}$ (non-ceruloplasmin $\mathrm{Cu}$ ), which is $\mathrm{Cu}$ that can be exchanged among peptides, amino acids, and albumin and that does not have a specific function but can be prone to oxidative stress (reviewed in Reference [83]). There are, in fact, two oxidation states of $\mathrm{Cu}$ : cuprous $\mathrm{Cu}(\mathrm{I})$ and cupric $\mathrm{Cu}$ (II) ions. $\mathrm{Cu}$ is mostly transported and buffered in its $\mathrm{Cu}(\mathrm{I})$ state intracellularly, bound to, for example, metallothioneins (MTs), Cu transporter 1 (Ctr1), and ATPases ATP7A/B, and $\mathrm{Cu}(\mathrm{I})$ in the free form is dangerous. $\mathrm{Cu}(\mathrm{II})$ is functionally important in enzymes/proteins that perform a precise function in the cell/tissue. These cuproenzymes play their catalytic function by using $\mathrm{Cu}(\mathrm{II}) / \mathrm{Cu}(\mathrm{I})$ redox cycles. However, if $\mathrm{Cu}$ is not employed for a catalytic function, it can enter $\mathrm{Cu}(\mathrm{II}) / \mathrm{Cu}$ (I) Fenton-type redox cycles and produce ROSs in a continuous manner. $\mathrm{Cu}(\mathrm{II})$ in non-ceruloplasmin $\mathrm{Cu}$ can increase the amount of the $\mathrm{Cu}$ redox pair that commonly participates in aggravating oxidative stress via Fenton-type chemistry: $\mathrm{Cu}(\mathrm{II})$ in the presence of a superoxide anion radical or biological reductants can be reduced to $\mathrm{Cu}(\mathrm{I})$, which is capable of decomposing hydrogen peroxide $\left(\mathrm{H}_{2} \mathrm{O}_{2}\right)$ to form reactive hydroxyl radicals $(\bullet \mathrm{OH}$ and $\mathrm{OH}-)$ via the Fenton-type reaction (refer to Reaction 1 and 2) [83,99].

$$
\begin{gathered}
\mathrm{Cu}(\mathrm{II})+\mathrm{O}_{2}-\bullet \rightarrow \mathrm{Cu}(\mathrm{I})+\mathrm{O}_{2}, \\
\mathrm{Cu}(\mathrm{I})+\mathrm{H}_{2} \mathrm{O}_{2} \rightarrow \mathrm{Cu}(\mathrm{II})+\bullet \mathrm{OH}+\mathrm{OH} \text {-(Fenton-type reaction) } .
\end{gathered}
$$

Oxidative stress via Fenton-type chemistry, driving ROS formation, including the highly reactive hydroxyl radical (HO•), is a hallmark of both AD [100] and normal aging of the human brain [101]. In fact, $\mathrm{Cu}$ dyshomeostasis has been observed in AD and facilitates $\mathrm{A} \beta$ oligomer formation and amyloid deposition, which, in turn, provoke oxidative damage by Fenton-type reactions [102]. The direct interaction of redox $\mathrm{Cu}$ ions with the $\mathrm{A} \beta$ peptide is one of the primary lesions in AD. Particularly, $\mathrm{Cu}(\mathrm{II})$ ions interact with $\mathrm{A} \beta$ at conserved histidine residues of Positions 6, 13, and 14 for metal coordination to engender di-tyrosine cross-linking between two A $\beta$ peptides, which promotes the irreversible oligomerization of $\mathrm{A} \beta$ [103]. These metal ions are reduced by $\mathrm{A} \beta$ from $\mathrm{Cu}(\mathrm{II})$ to $\mathrm{Cu}(\mathrm{I})$ with a concomitant generation of ROSs, hydrogen peroxide $\left(\mathrm{H}_{2} \mathrm{O}_{2}\right)$, and $\mathrm{HO} \bullet$, which lead to the formation of proapoptotic lipid peroxidation products, such as 4-hydroxynonenal (HNE) [104].

Moreover, elevated $\mathrm{Cu}$ promotes ROS formation and its cytotoxic effects by reducing the level of glutathione (GSH) (a substrate for enzymes that removes ROSs). The probable reason for the reduced GSH level in the blood of $\mathrm{Cu}$-exposed animals may be related to the interaction between $\mathrm{Cu}$ and $\mathrm{GSH}$, which forms a $\mathrm{Cu}(\mathrm{I})-[\mathrm{GSH}]$ complex that is responsible for converting molecular oxygen $\left(\mathrm{O}_{2}\right)$ into superoxide [105]. GSH depletion has been pointed out as the main driver of ferroptosis in AD, which is a special modality of cell death determined by an iron-dependent phospholipid peroxidation [106]. The drop in GSH provides a link between $\mathrm{Cu}$ imbalance and iron dysmetabolism tied to AD risk and progression [107]. The expression of Cu-dependent enzymes, such as $\mathrm{Cu} / \mathrm{Zn}$ SOD1 and antioxidant protein 1 (ATOX1), was markedly reduced in multiple microarray studies of $\mathrm{AD}$ patients, reinforcing the notion that a lack of $\mathrm{Cu}$, by reducing host antioxidant defenses, plays a pivotal role in AD pathology [108,109].

Consistently, chronic exposure of $0.13 \mathrm{ppm} \mathrm{Cu}$ in drinking water, along with spatial memory impairment, has caused variation in the expression of 31 hippocampal mitochondrial proteins (15 increased and 16 decreased) and 46 hippocampal nuclear proteins (18 increased and 28, including synapsin-2 and SOD1, decreased) in Cu-treated versus un- 
treated mice [109]. In addition to the antioxidant role, SOD1 also exerts anti-inflammatory functions. In concordance with this notion, reduced expression of SOD1 can exacerbate ROS accumulation and chronic neuroinflammation [110]. These processes can produce a loss of functional $\mathrm{Cu}$ in protein-bound pools that can reduce energy production by CCO and defense against oxidative stress by SOD1, which are central components for brain function and aging [111].

The greater frequency with late onset $\mathrm{AD}$ subjects has been reported with inherited mutations of mitochondrial CCO genes [112], which is suggestive of impaired CCO activity as a risk factor for AD. Furthermore, the enzymatic activity of SOD1 has been observed to be impaired in AD brains [113] and in transgenic APP mice [114], which may be due to a decline in occupancy at the active site of $\mathrm{Cu}$. Ceruloplasmin has also been observed to be lower in the brain of $\mathrm{AD}$ patients [115]. In fact, ceruloplasmin inhibits iron (Fe)-mediated oxidative alterations by oxidizing Fe (II) to Fe (III) [116], which is indicative of protective effects against the onset of AD. Thus, depletion of $\mathrm{Cu}$-bound ceruloplasmin can trigger oxidative stress induced alterations in AD brains.

The findings sustaining a gain in the toxic function of increased labile $\mathrm{Cu}$ in the synaptic cleft reported in Section 3.4 and those regarding the loss of functional $\mathrm{Cu}$ in protein-bound pools reported in this section fit well with the $\mathrm{Cu}$-AD hypothesis (reviewed in Reference [84]).

\subsection{Abnormal Cu Handling in Mitochondria}

$\mathrm{Cu}$ is critical for the normal functioning of mitochondria (during mitochondrial respiration), and any functional $\mathrm{Cu}$ loss may impair the electron transport chain function and deplete neuronal energy. This event may further trigger a leakage of ROSs from electron chain transporters followed by impairment in the mitochondrial transmembrane potential and ROS-induced apoptosis [117].

$\mathrm{Cu}$ acts as a cofactor for enzyme $\mathrm{CCO}$, which catalyzes the reduction of molecular oxygen $\left(\mathrm{O}_{2}\right)$ to water $\left(\mathrm{H}_{2} \mathrm{O}\right)$. This results in the generation of the electrical gradient, which is used in ATP synthesis by mitochondria [118]. $\mathrm{Cu}$ concentration within mitochondria is controlled by $\mathrm{Cu}$-transporting ATP7B, a Cu pump that may be involved in the export of $\mathrm{Cu}$ from mitochondria. CCO Cu chaperone 17 (Cox17) directs the $\mathrm{Cu}$ in both the cytosol, as well as intermembrane space, of mitochondria. Three $\mathrm{Cu}$ ions are present in the active assembled form of CCO, Complex IV of the electron transport chain. Hence, inefficient $\mathrm{Cu}$ transport to mitochondria may result in a poor assembly of individual CCO subunits into the functional holoenzyme $[119,120]$. Consequently, the accumulation of electrons upstream and leakage from Complexes I and III can generate ROSs by reducing oxygen to the superoxide, which causes the release of CCO into the cytosol to activate caspase-9 for the execution of the apoptotic pathway. Furthermore, any mutation of Cox 17 might also affect the function of mitochondrial respiration [119]. Any of such defects in CCO biogenesis due to the loss of $\mathrm{Cu}$ impair energy production and mitochondrial dysfunction, which leads to $\mathrm{AD}$ and other neurodegenerative diseases [121]. Of note, $\mathrm{CCO}$ is expressed in $2 / 3$ cells of the molecular layer of the dental gyrus in the hippocampus [122]. A number of studies have reported a decrease in CCO expression [110,123] or activity [124] and impaired energy metabolism in an AD patient's brain [125-127]. It is well evident that $\mathrm{Cu}$ is required by various important enzymes for their catalytic activity, which is altered in AD brains.

\subsection{Accumulation of the Amyloid Peptide, Protein Misfolding, and Plaque Formation}

In AD, APP undergoes fragmentation and yields peptides of variable length, which are known as amyloids. It precipitates and results in the production of both extracellular $\mathrm{A} \beta$ plaques containing oxidized and metal-bound $\mathrm{A} \beta$ peptides in the brain of $\mathrm{AD}$ patients, known as senile plaques and intracellular NFTs [128]. Cu can drive the intracellular aggregation of hyperphosphorylated $\beta$-sheet-rich (tubulin-associated unit) tau due to the presence of $\mathrm{Cu}$-binding sites on these proteins $[128,129]$. It is pertinent to note that 
APP expression acts as a key regulator of neuronal $\mathrm{Cu}$ homeostasis [130]. APP has a specific $\mathrm{Cu}$ binding domain (CBD) located in the N-terminal cysteine-rich region, and this domain can strongly coordinate $\mathrm{Cu}$ (II). A CBD can influence $\mathrm{Cu}$ homeostasis and $\mathrm{A} \beta$ production. Importantly, $\mathrm{Cu}$ binding with the $\mathrm{Cu}$ binding domain of APP can greatly favor the reduction of $\mathrm{Cu}(\mathrm{II})$ to $\mathrm{Cu}(\mathrm{I})$, which, in turn, triggers the catalytic generation of ROSs via Fenton-type chemistry and $A \beta$ aggregation [131]. It has been observed that the binding of $\mathrm{Cu}$ with $A \beta$ accelerates the rate of spontaneous $A \beta$ accumulation in contrast to the absence of metal ions $[132,133]$. $\mathrm{Cu}(\mathrm{II})$ shows a sub-nanomolar affinity for $\mathrm{A} \beta(1-40)$ and $A \beta_{(1-42)}$ (for monomers and fibers) [134] and a stronger femtomolar affinity for truncated forms of $A \beta_{(11-40)}$ and $A \beta_{(4-40)}$, which are capable of affecting fiber assembly [135]. On the contrary, information regarding the affinity of $\mathrm{Cu}(\mathrm{I})$ for $\mathrm{A} \beta$ is scarce but has been reported for $A \beta_{(1-16)}$ [136]. As previously discussed, the disruption of $\mathrm{Cu}(\mathrm{II})$ homeostasis in the brain is a prominent characteristic of AD, which is evidenced from the presence of a 26-fold greater concentration of $\mathrm{Cu}$ (II) ions within senile plaques of AD patients, compared with the extracellular space of healthy individuals [137]. It is noteworthy that $\mathrm{Cu}$ in more damaged AD brain areas likely decreases in association with a consistent decrement of $\mathrm{Cu}$ within neuronal cells [96,138], while labile $\mathrm{Cu}$ has a $20 \%$ increase [68]. Therefore, $\mathrm{A} \beta$ plaques are regarded as a 'metal sink' [139].

Metal ions have been reported to alter the kinetics and thermodynamics of the form and structure of the aggregates. Both in vitro and in vivo studies have suggested that $\mathrm{Cu}(\mathrm{II})$ ions play an important role for $\mathrm{A} \beta 42$ aggregation via the amyloid cascade process, involving a transition of a normal soluble amyloid peptide to an aggregated and fibrous form. $\mathrm{Cu}(\mathrm{II})$ promotes different types of aggregation states by depending upon multiple factors, including $\mathrm{pH}$, protein concentration, metal-protein ratio, temperature, buffer conditions, and stirring during incubation. $\mathrm{Cu}$ ions bind rapidly to coordination sites of histidine, with high affinity in a monomeric $A \beta[140]$, thereby stabilizing $A \beta$ aggregates [141]. Indeed, the interaction between $\mathrm{Cu}$ ions and monomeric $\mathrm{A} \beta$ potentiates the precipitation and accumulation of insoluble peptide aggregates in the amyloid plaque [142]. Notably, recent human-based evidence using synchrotron X-ray spectromicroscopy has observed the presence of newly discovered elemental metallic $\mathrm{Cu}(0)$ (zero-oxidation state) within amyloid plaque cores isolated from the grey matter of AD brains, which is strongly suggestive of the role of metals in the etiology of AD [85]. Furthermore, Cu exposure may also lead to modifications in the distribution, activity, and levels of enzymes, such as BACE1 [143], $\alpha$-secretase [144], and presenilins, which cause the processing of APP to amplify the generation of $\mathrm{A} \beta$.

\subsection{Increased Labile $\mathrm{Cu}$ in the Synaptic Cleft}

$\mathrm{Cu}$ in the synaptic cleft can directly or indirectly regulate the activity of neurotransmitter receptors, such as N-methyl-D-aspartate (NMDA), $\alpha$-amino-3-hydroxy-5-methyl-4isoxazolepropionic acid (AMPA), gamma-aminobutyric acid (GABA), and purinoreceptor (P2X) receptors, thus affecting neuronal excitability $[145,146]$. In contrast, neurotransmission can also influence trafficking and the delivery of $\mathrm{Cu}$ in neuronal cells. Moreover, $\mathrm{Cu}$ has also been reported to modulate the trafficking of synaptic vesicles and proteins [109] and the interaction of proteins that are connected with neurodegenerative diseases, such as APP, the prion protein (PrP), and $\alpha$-synuclein ( $\alpha$-syn). At the synapse, APP can facilitate the reduction of $\mathrm{Cu}$ (II) to $\mathrm{Cu}(\mathrm{I})$ and, thus, enable the $\mathrm{Cu}$ transporter 1 (CTR1) function, and ATP7A/B can promote $\mathrm{Cu}$ translocation into vesicles that can then be released at the synaptic cleft. CTR1 transfers Cu(I) to Cu-chaperone for SOD1 (CCS) and metallothionein $(\mathrm{MT})$, and CCS delivers $\mathrm{Cu}(\mathrm{I})$ to SOD1. The catalytic reduction of molecular oxygen $\left(\mathrm{O}_{2}\right)$ to water $\left(\mathrm{H}_{2} \mathrm{O}\right)$ by cytochrome c oxidase $(\mathrm{CCO})$ generates an electrical gradient used by mitochondria to create ATP [147]. Excess $\mathrm{Cu}$ ions are released at glutamatergic synapses in the form of labile $\mathrm{Cu}$ not bound to proteins during transmission in a recycling process regulated by PrP or from the postsynaptic terminal upon stimulation of the N-methyl-Daspartate (NMDA) receptor downregulating the NMDA receptor activity [66,147]. Labile 
$\mathrm{Cu}$ can disrupt the APP capacity to reduce $\mathrm{Cu}(\mathrm{II})$ to $\mathrm{Cu}(\mathrm{I})$ and enable $\mathrm{Cu}$ transporter 1 (CTR1) to facilitate the ATP7B translocation of $\mathrm{Cu}$ into synaptic vesicles. This phenomenon facilitates $\mathrm{Cu}-\mathrm{A} \beta$ formation and oxidative stress as depicted above. Conversely, it has been reported that increased labile $\mathrm{Cu}$ in the cleft may enhance synaptic activity, which might, in turn, be either toxic or non-toxic [148]. However, processes of synaptic activity modulation must be strictly regulated. In the case of AD, our hypothesis is that these processes are disturbed by labile $\mathrm{Cu}$ excess (for a specialized review, refer to Reference [84]).

\subsection{Advanced Glycation End-Products}

Advanced glycation end-product (AGE) formation is a known feature of AD [120]. Cu accelerates the AGE formation, which also promotes protein glycoxidation [149]. AGEs damage the arterial wall in diabetes and facilitate a progressive Cu-trapping potential [150]. In $\mathrm{AD}$, insoluble $\mathrm{A} \beta$ plaques contain high levels of AGEs and transition metal ions, such as $\mathrm{Cu}, \mathrm{Zn}$, and Fe [151]. AGEs are formed by non-enzymatic reactions of lysine and arginine residues of proteins, with reducing sugars or dicarbonyl compounds, such as methylglyoxal (MG) and glyoxal formed during defective glucose metabolism or oxidative stress [152]. A $\beta$ glycation by sugars generates the free radical superoxide anion $\left(\mathrm{O}_{2}{ }^{-}\right)$, which, upon reacting with $\mathrm{Cu}(\mathrm{II})$, converts to $\mathrm{HO} \bullet$ via a Fenton-type reaction [153].

Mechanistically, AGEs exacerbate neurotoxicity by upregulating receptors of AGEs, namely RAGE expression and glycogen synthase kinase-3 (GSK-3) activation. The overexpression of RAGEs has been found in AD brains and specifically acts as a binding site for $A \beta$ at the plasma membrane of different cells, including neurons, microglial cells, and endothelial cells, of the vessel wall [154]. The interaction of AGEs with surface RAGEs of neural cells in the brain [154] perturbs cellular functions by stimulating $A \beta$-mediated oxidative stress, NF- $\mathrm{kB}$ [155], the neuronal expression of macrophage colony-stimulating factor [156], and cell death [157]. Consistently, RAGE-mediated signaling induced by glycated $A \beta$ has been reported to be responsible for learning/memory deficit in transgenic models of AD [158]. A $\beta$-AGEs may also cause memory and synapse impairment by activating RAGE-dependent GSK-3 induction, which is evident from the pathological changes of $A \beta$-AGEs after exposure to the GSK- 3 inhibitor. RAGEs can also aggravate the neurotoxicity of $A \beta$-AGEs by mediating the intraneuronal transport of $A \beta$ across the $\mathrm{BBB}$, thereby causing their deposition in the brain, which is responsible for the age-related memory decline in AD models [159].

\section{Altered $\mathrm{Cu}$ Homeostasis in Microglia and Astrocyte in AD}

Trace metal concentrations in different brain areas are deregulated during aging and inflammation. This particularly occurs at the choroid plexus due to a perturbed BBB. Microglia and astrocytes can restrain metals and protect neurons from metal toxicity [160-162].

\subsection{Microglia Role in $C u$ Imbalance Linked to $A D$}

As summarized above, biometal dyshomeostasis plays an important role in the pathogenesis of $\mathrm{AD}$. In this section, we will discuss how $\mathrm{Cu}$ exposure can also prompt the activation of microglia-mediated neuroinflammation and trigger neuronal death and memory deficits [163]. There is scanty knowledge available so far regarding the dual protective or detrimental role of microglial metal homeostasis in pathogenesis of AD brains. In relation to neuroinflammation, the $\mathrm{Cu}-\mathrm{A} \beta$ complexes augment the release of TNF- $\alpha$, as well as IL-1 $\beta$, and affect the phagocytic behavior of the murine BV2-microglia phenotype with a concomitant downregulation of LRP-1 expression in human primary microvascular endothelial cells $[90,91,162]$. The decreased expression of LRP-1 can further interfere with the transcytotic clearance of $\mathrm{A} \beta$, thereby aggravating neuroinflammation $[164,165]$.

Consistent with these findings, chronic $\mathrm{Cu}$ exposure has been demonstrated to suppress LRP-1 in the endothelial cortical vasculature of C57BL6 mice treated with $\mathrm{Cu}$ $(0.13 \mathrm{mg} / \mathrm{L})$ [91]. Moreover, trace amounts of $\mathrm{Cu}(0.21 \mathrm{ppm})$ have been reported to induce $A \beta$ deposits and their toxic effects, which lead to the activation of microglia and 
stimulate the toxicity of microglia to neighboring neurons via TNF-mediated signaling in a murine model co-treated with cholesterol and $\mathrm{Cu}$ [166]. A $\beta: \mathrm{Cu}(\mathrm{II})$ complexes are related to neuroinflammation via involvement of TNF- $\alpha$ signaling accompanied by the oxidative-stress-induced apoptosis (caspase- 3 activation). At the same time, $\mathrm{Cu}$-induced TNF- $\alpha$ inflammatory signaling promotes the degradation of I $\kappa B$, which implies the elevated expression of NF- $\mathrm{KB}$ in the hippocampus and cerebral cortex. These findings suggest that inflammatory responses in activated microglial and neighboring neuronal cells aggravate the neurotoxicity that ultimately leads to the neurodegenerative process [166].

$\mathrm{Hu}$ and colleagues reported that subneurotoxic doses $(20 \mu \mathrm{M})$ of $\mathrm{Cu}$ (II) trigger mitochondrial ROS-NF- $\mathrm{kB}$ signaling that might be responsible for the release of TNF- $\alpha$ and $\mathrm{NO}$ in a dose- and time-dependent manner in rat and murine microglial cell lines. These proinflammatory factors may act synergistically to elicit the morphological alteration of microglia from resting to active states, which would eventually lead to microglia-mediated neuroinflammation and damage $[163,167]$. In line with this statement, another study suggested that subneurotoxic concentrations of the $\mathrm{Cu}(\mathrm{II})-\mathrm{A} \beta$ complex treatment (but not $\mathrm{A} \beta$ or $\mathrm{Cu}(\mathrm{II})$ alone; $50 \mu \mathrm{M}$ ) provoke the consequences of $\mathrm{A} \beta$ by switching the phagocytic to the inflammatory phenotype of microglia with a simultaneous release of TNF- $\alpha$ and $\mathrm{NO}$ [163]. The A $\beta$-primed microglia proinflammatory phenotype activation may involve NF- $\mathrm{KB}$ activation and NOX-independent mitochondrial ROS production, which can further trigger the release of proinflammatory cytokines and chemokines. In fact, $\mathrm{Cu}$ (II) may act as a cofactor to potentiate the effect of $A \beta$ on microglial activation and the subsequent neurotoxicity [168]. Kitazawa et al. have reported that $\mathrm{Cu}$ exposure can effectively reduce the phagocytic clearance of $A \beta$ and aggravate $A \beta$-induced pro-inflammatory cytokine release (IL-1 $\beta$, TNF- $\alpha$, and IL-6), which shows a robust impact on the downregulation of LRP1 expression, as well as impairment in microglial phagocytic activation, and, finally, leads to a vicious cycle responsible for the pathological accumulation of $A \beta$ in the brain [164].

A recent in vivo transcriptomic analysis of microglia in neurodegeneration has highlighted that excess $\mathrm{Cu}$ intake through drinking water shifts the microglial phenotype towards degenerative expression by increasing the translation of degenerative genes and repressing homeostatic genes, which thereby accelerates cognitive decline and may illustrate one of the major mechanisms linking $\mathrm{Cu}$ dyshomeostasis to the AD pathology [169]. In vivo and in vitro analysis have suggested that $\mathrm{Cu}$ (II) diminishes the microglia-mediated clearance of $A \beta 1-42$ via modulating the mammalian target of rapamycin (mTOR) transcription factor EB (TFEB) axis attributable for the suppression or impairment of lysosomal biogenesis and autophagic flux. Additionally, $\mathrm{Cu}(\mathrm{II})$ negatively targets the expression of TFEB genes, including LAMP $1 / 2$ and Cat $B$, which are responsible for maintaining lysosomal integrity and $A \beta$ clearance, respectively [170]. This effect of $\mathrm{Cu}(\mathrm{II})$ implies one of the novel mechanisms for the $\mathrm{Cu}$ (II)-induced neurodegeneration in $\mathrm{AD}$ [170].

In aging, interferon $\gamma$-activated microglial cells have been connected with high $\mathrm{Cu}$ uptake mediated by an enhanced expression of a $\mathrm{Cu}$ importer, specifically CTR 1 in the choroid plexus [161]. Similarly, Ashraf et al. have observed the enrichment of $\mathrm{Cu}$ in aging ventricles, likely due to inflammation, indicating a compromised barrier system. Additionally, age-related glial dystrophy/senescence has also been supposed to perturb metal homeostasis due to oxidative stress and, thus, amplify the risk of neurodegenerative diseases [171]. Notably, an in vitro study revealed that increased concentrations of ceruloplasmin in $\mathrm{AD}$ patients can potentiate the proinflammatory activation of microglial cells by upregulating NO release and the mRNA profile of encoding interleukins and enzymes, such as cyclooxygenase-2 (COX-2) or NADPH oxidase [172].

Alternatively, the intracellular sequestration of $\mathrm{Cu}(\mathrm{II})$ has been reported to activate the neuroprotective phenotype of microglia, which may further abrogate $A \beta$ plaque formation [173]. Mechanistically, activated microglia surrounding $A \beta$ plaques upregulate the expression of ATP7A, which may favor overall $\mathrm{Cu}(\mathrm{II})$ uptake by augmenting CTR1 $\mathrm{Cu}$ importer expression, as observed in a TgCRND8AD mice model [161]. Consistent with this, the upregulation of ATP7A expression was also observed in BV-2 microglial cells 
treated with proinflammatory agents (such as IFN- $\gamma$ ), which elevated Cu uptake and CTR1 expression in AD patients [161]. These observations revealed that $\mathrm{Cu}$ uptake via CTR1 and sequestration via ATP7A can alter the $\mathrm{Cu}$ homeostasis in activated microglial cells at sites of amyloidogenesis in AD brains. Hence, the uptake and sequestration of $\mathrm{Cu}(\mathrm{II})$ by microglia confers one of the key neuroprotective mechanisms in AD, which limits the labile extracellular $\mathrm{Cu}$ requisite for $\mathrm{A} \beta$ aggregation and plaque formation [161].

On the contrary, an in vivo study has revealed that the transfection of fibroblast cell lines with ATP7A can cause the depletion of intracellular $\mathrm{Cu}$, which, by downregulating APP expression, inhibits A $\beta$ production [174]. However, there is also a contradictory report stating that the deficiency of $\mathrm{Cu}$ can lead to aberrant microglial activation and subsequently contribute to neurodegenerative diseases [175]. This effect suggests that $\mathrm{Cu}$ plays a key role in the maintenance of microglial homeostasis, as well as in AD, and its role/concentration changes in different regions of brain/glial cells also depend upon the disease state, i.e., during early phase, the middle stage, and the final, full blown AD stage, or in some specific subset of AD patients who are genetically more susceptible to $\mathrm{Cu}$ imbalance.

Moreover, the spectrum of the microglial phenotype depends upon the redox capability of $\mathrm{Cu}$. This is evident from the role of the $\mathrm{Cu}$ ion (I) in polarizing activated microglia from the proinflammatory M1 phenotype to the anti-inflammatory M2 phenotype by inhibiting NO production and regulating S-nitrosothiol signaling [176,177]. This observation highlights how a $\mathrm{Cu}$ valence state $(\mathrm{Cu}(\mathrm{I})$ and $\mathrm{Cu}(\mathrm{II}))$ may act as a key factor in the maintenance of the microglial cell phenotype. Thus, neurotoxicity may depend on their different redox capabilities. According to $\mathrm{Du}$ et al., $\mathrm{Cu}(\mathrm{I})$ decreases $\mathrm{A} \beta 42$ aggregation and, in turn, hampers ROS production as compared to $\mathrm{Cu}(\mathrm{II})$, which is indicative of decreased neurotoxicity [178]. On the other hand, $\mathrm{Cu}(\mathrm{II})$ can predominately bind monomeric $\mathrm{A} \beta$ peptides (1:1 stoichiometry) at physiological $\mathrm{pH}$ and lead to a $\mathrm{Cu}(\mathrm{II})-\mathrm{A} \beta$ complex formation [179]. This phenomenon may explain the different roles of microglia in neurotoxicity mediated by $\mathrm{Cu}(\mathrm{I})$ and $\mathrm{Cu}(\mathrm{II})$ during the pathogenesis of AD.

Thus, it is mandatory to understand the exact role of $\mathrm{Cu}$ homeostasis in the regulation of immune responses in the brain, particularly its role in microglia-mediated neurotrophic or neurotoxic effects in $\mathrm{AD}$, which may provide for a novel therapeutic strategy for AD.

\subsection{Aberrant Astrocyte Behavior and Excess Labile $\mathrm{Cu}$}

Astrocytes are known to maintain nervous tissue by regulating extracellular ion homeostasis, synaptic transmission, and the supply of metabolites [180]. Additionally, astrocytes are well known regulators of the homeostasis of redox-active metals, specifically $\mathrm{Cu}$ in the brain by influencing $\mathrm{Cu}$ uptake and export [181,182]. Previous studies have reported that cultured astrocytes are able to efficiently store $\mathrm{Cu}$ (apparent $\mathrm{Km} \approx 10 \mu \mathrm{M}$ for Cu uptake) [183-186]. Cultured astrocytes can accumulate Cu via CTR1-dependent and -independent mechanisms that may include divalent metal transporter 1 (DMT1) and members of the Zrt/IRT-like protein (known as ZIP) family [182,184]. An ecto-cuprireductase and/or astrocyte-derived ascorbate can mediate the reduction of extracellular $\mathrm{Cu}$ (II) to $\mathrm{Cu}(\mathrm{I})$ for astrocytic uptake by Ctr1 and DMT1. Interestingly, astrocytes are believed to be equipped with machinery that can deal with even higher amounts of $\mathrm{Cu}$ and, hence, be exceptionally resistant to Cu-mediated toxicity $[187,188]$. A possible reason is that astrocytes buffer excess $\mathrm{Cu}$ by increasing cellular tripeptide GSH and metallothioneins (MTs) - a family of metal-binding cysteine rich proteins [182,189]. Moreover, GSH also participates in the cellular Cu transport [190]. During Cu overload, excess Cu binds with GSH and MTs in astrocytes and, thereby, prevents $\mathrm{Cu}$-induced neurotoxicity. Additionally, $\mathrm{Cu}$ is shuttled to target proteins by specific $\mathrm{Cu}$ chaperons, e.g., CCS to SOD1, COX17 to SCO1/2, COX11 to $\mathrm{CCO}$, and ATOX1 to ATP7A. Astrocytes export $\mathrm{Cu}$ by expressing ATP7A, which undergoes trafficking between the trans-Golgi network and vesicular structures [182]. Prion protein has also been suggested to mediate $\mathrm{Cu}$ uptake or export in astrocytes [183].

Astrocytes, the $\mathrm{Cu}$ depots of the brain [5], play a paramount role in the homeostasis of the redox-active metal $\mathrm{Cu}$, which upon dyshomeostasis is detrimental to cell functioning 
and survival [9]. Cu levels beyond the handling capacity of astrocytes may initially result in a cascade of protective events to reduce labile $\mathrm{Cu}$ neurotoxicity, thus activating astroglia, astrocyte hypertrophy, and related events $[5,191,192]$. Previous in vivo studies observed that excess $\mathrm{Cu}$ can decrease the cell viability in cultured astrocytes $[187,193]$. The toxic mode of action of $\mathrm{Cu}$ was observed with a significant increase in hydroperoxide levels due to the valency shift from the $\mathrm{Cu}$ (II) to $\mathrm{Cu}$ (I) state, which suggests a critical role of oxidative stress in the mode of action of $\mathrm{Cu}$. Excess amounts of $\mathrm{CuSO}_{4}$ induce mitochondrial permeability transitions (mPTs), which are evident from a significant dissipation of the mitochondrial membrane potential $(\Delta \Psi \mathrm{m})$ and death at $48 \mathrm{~h}$ in cultured astrocytes. However, pre-treatment with antioxidants may reverse the effect of $\mathrm{Cu}$-induced $\mathrm{mPT}$ and the oxidative death of astrocytes. These observations support that oxidative stress and mitochondrial dysfunction are involved in Cu toxicity [187,194]. In agreement with this, $\mathrm{Cu}$ at subcytotoxic concentrations exerts cytotoxic potential $\left(\mathrm{EC}_{30}: 250 \mu \mathrm{M}\right)$ by impairing mitochondrial function specifically affecting $\Delta \Psi \mathrm{m}$, which eventually triggers ROS production, suggesting an involvement of mitochondria as a potential target organelle accountable for the toxic effects of $\mathrm{Cu}$ in a human astrocytic cell model [189]. Impaired CNS metal homeostasis leads to ROS production at affected sites depending on the severity/extent, which may cause irreversible damage and with time lead to neurodegeneration.

Consistent with the $\mathrm{Cu}-\mathrm{AD}$ hypothesis [84], AD patients exhibit values of nonceruloplasmin $\mathrm{Cu}$ that are commonly found in Wilson disease, the paradigmatic disorder of $\mathrm{Cu}$ accumulation or toxicosis caused by mutations in the $A T P 7 B$ gene. In Wilson's disease, astrocytes likely accumulate large amounts of excess $\mathrm{Cu}$ present in the brain, protecting neurons from $\mathrm{Cu}$ toxicity. This ability appears to be related with the upregulation of GSH and MTs [182]. The depletion in GSH levels is a feature of the aging brain and might be associated with neurodegenerative disease progression, including impairments in cognitive function and ferroptosis in AD [108,195]. Observations on AD patients have shown that around 3\% of non-ceruloplasmin Cu can cross the BBB [196]. This provides some hints about the potential mechanism of $\mathrm{Cu}$ imbalance occurring with aging, and non-ceruloplasmin $\mathrm{Cu}$, if it continues to rise unchecked, will disturb labile $\mathrm{Cu}$ balance in the interstitial space around neurons and glial cells, which might further trigger protective reversible reactive astrogliosis events, such as ischemic preconditioning or ischemic tolerance [197], which, in turn, may result in irreversible neuroinflammatory response, which can be detrimental to neuronal health. As shown previously, higher serum non-ceruloplasmin $\mathrm{Cu}$ levels are associated with clinical deficits that are features of an AD picture, including a lower mini-mental state examination (MMSE) score [198] and peculiar neurophysiological and brain anatomical damage (reviewed in Reference [199]), even though the exact mechanism needs to be elucidated. Redox active non-ceruloplasmin $\mathrm{Cu}$ in the context of a disturbed buffering capacity of astrocytes might, thus, contribute to AD neurodegeneration mirroring Wilson's disease, and this provides for a window of opportunity to reverse this damaging process by chelating excess labile $\mathrm{Cu}[191,192]$.

In pathological conditions, such as $\mathrm{AD}$ and other neurodegenerative diseases, any disturbance in the disposition of $\mathrm{Cu}$ has been reported to lead to an impaired trafficking of $\mathrm{Cu}$ from astrocytes to neurons [182]. This is likely due to the enrichment of $\mathrm{Cu}$ chaperone proteins in astrocytes. $\mathrm{Cu}$ can especially generate $\mathrm{HO} \bullet$ in astrocytes due to the abundance of $\mathrm{Cu}$ carrier protein-chaperones [186]. This is evident from the intracellular $\mathrm{Cu}$ that augments the expression of two markers for endoplasmic reticulum stress response (GRP78 and GRP94 protein), which are involved in oxidative stress response in lead-exposed astrocytes [186].

Another line of research proposes that astrocytes participate in a neurotrophic, as well as neuroprotective, role, and the inappropriate function of these cells may lead to an onset of neurodegenerative diseases [200]. Meanwhile, astrocytes can transform from an acute to a chronically active 'proinflammatory' phenotype by the dysregulation of calcineurin/nuclear factor of activated T-cell (CN/NFAT) signaling [201], which perpetuates neuroinflammatory signaling cascades and participates in the progression of neurode- 
generative diseases. Indeed, activated astrocytes appear as an early hallmark of AD and started consistently increasing with the development of clinical and pathological manifestations [202]. As discussed in detail, $\mathrm{Cu}$ is known to accelerate the sequential cleavage of APP to produce extracellular A $\beta$ monomers, which undergo oligomerization to form complex $A \beta$ complexes that play a crucial role in brain inflammation. In vitro evidence has suggested that $A \beta$ plaques and fibrils are endogenous stimuli for turning on astrogliosis or reactive astrocytosis [203]. $A \beta$ oligomers may induce inflammatory response by affecting immune constituents of astrocytes remarkably via activating various PRRs, including TLR 2/4, RAGEs [204], and the inflammasomes [205]. The interaction between A $\beta$ oligomers and TLR $2 / 4$ on astrocytes can stimulate inflammatory responses, which elicit toxic proinflammatory mediators that affect neurons and, thereby, cause neuroinflammation in AD brains [203]. Several in vitro and in vivo studies, by generating a number of inflammatory mediators, including IL- $1 \beta$, IL-6, MCP-1, macrophage inflammatory protein (MIP), and $\mathrm{NO}$, have identified that the same phenomenon is responsible for neuroinflammation in AD [206-208].

It is not surprising that astrocyte deterioration causes neurotoxicity and, thereby, leads to aging and neurodegenerative disease. $\mathrm{Cu}$ at a physiological concentration in complexes with the metal chelator neocuproine (NCP) may cause the apoptosis of rat cortical astrocytes by inducing oxidative neurotoxicity. In fact, the NCP facilitates intracellular $\mathrm{Cu}$ uptake and, thereby, provokes an increase in ROS production, the dissipation of $\Delta \Psi \mathrm{m}$, and the depletion of GSH and ATP. Consequently, this results in the activation of downstream molecules, such as c-Jun N-terminal kinase (JNK), as well as caspase-3, and, ultimately, leads to PARP degradation [188]. The same group has also observed that the PDTC-Cu(II) complex induces astrocyte dysfunction through an apoptotic process with a subsequent activation of oxidative stress and JNK [209].

Griffin and colleagues have described that the long-term stimulation of these mediators can activate a chronic "cytokine cycle," which is harmful in affecting disease progression [210]. Astrocytes express RAGEs that function as PRRs for A $\beta$ oligomers induced by $\mathrm{Cu}$ accumulation [204]. The A $\beta$ binding to RAGEs causes a proinflammatory reaction, which may be mediated through the NF- $\mathrm{KB}$ transcription pathway. Additionally, RAGEs are also involved in accelerating $A \beta$ transport from plasma to the $C N S$, which suggests their involvement in AD pathogenesis [211]. Askarova et al. have revealed that the $\mathrm{A} \beta_{42}$-RAGE interaction can activate the assembly of the NADPH oxidase complex, which further leads to the induction of ROS generation, the mitogen-activated protein kinase/extracellular signal-regulated kinase 1/2 (MAPK/ERK) pathway, and the phosphorylation of cytosolic phospholipase $\mathrm{A}_{2}\left(\mathrm{cPLA}_{2}\right)$ in primary astrocytes [212]. Additionally, astrocytes have been reported to hinder microglia-mediated $A \beta$ plaque clearance by the secretion of glycosaminoglycan-sensitive molecules $[213,214]$, and this indirectly facilitates $\mathrm{A} \beta$ accumulation in $\mathrm{AD}$ brains.

On the contrary, Choo et al. have recently demonstrated that the Cu-bis (thiosemicarbazone) complex $\mathrm{Cu}^{\mathrm{II}}$ (atsm) alleviates brain inflammation induced by the peripheral administration of bacterial LPS. $\mathrm{Cu}^{\mathrm{II}}(\mathrm{atsm})$ significantly reduces the secretion of NO, MCP1 , and IL-6 in astrocytes. These robust anti-inflammatory effects of $\mathrm{Cu}^{\mathrm{II}}$ (atsm) may be connected with increased cellular Cu levels and MT-1 in astrocytes [215].

\section{Conclusions}

Though not exhaustive, the evidence provided shows that aberrant glial cell biology might be involved in the deprivation of the physiological metal microenvironment around neurons, which can have direct injurious effects on functioning and viability of brain neuron cells. On this basis, it is tempting to speculate that microglia and reactive astrogliosis associated with $\mathrm{Cu}$ ion imbalance might play a role in processes of neurodegeneration associated with dementia encompassing the energy depletion of high-energy demand neurons, oxidative stress, protein misfolding, and glycoxidation (Figure 1). 


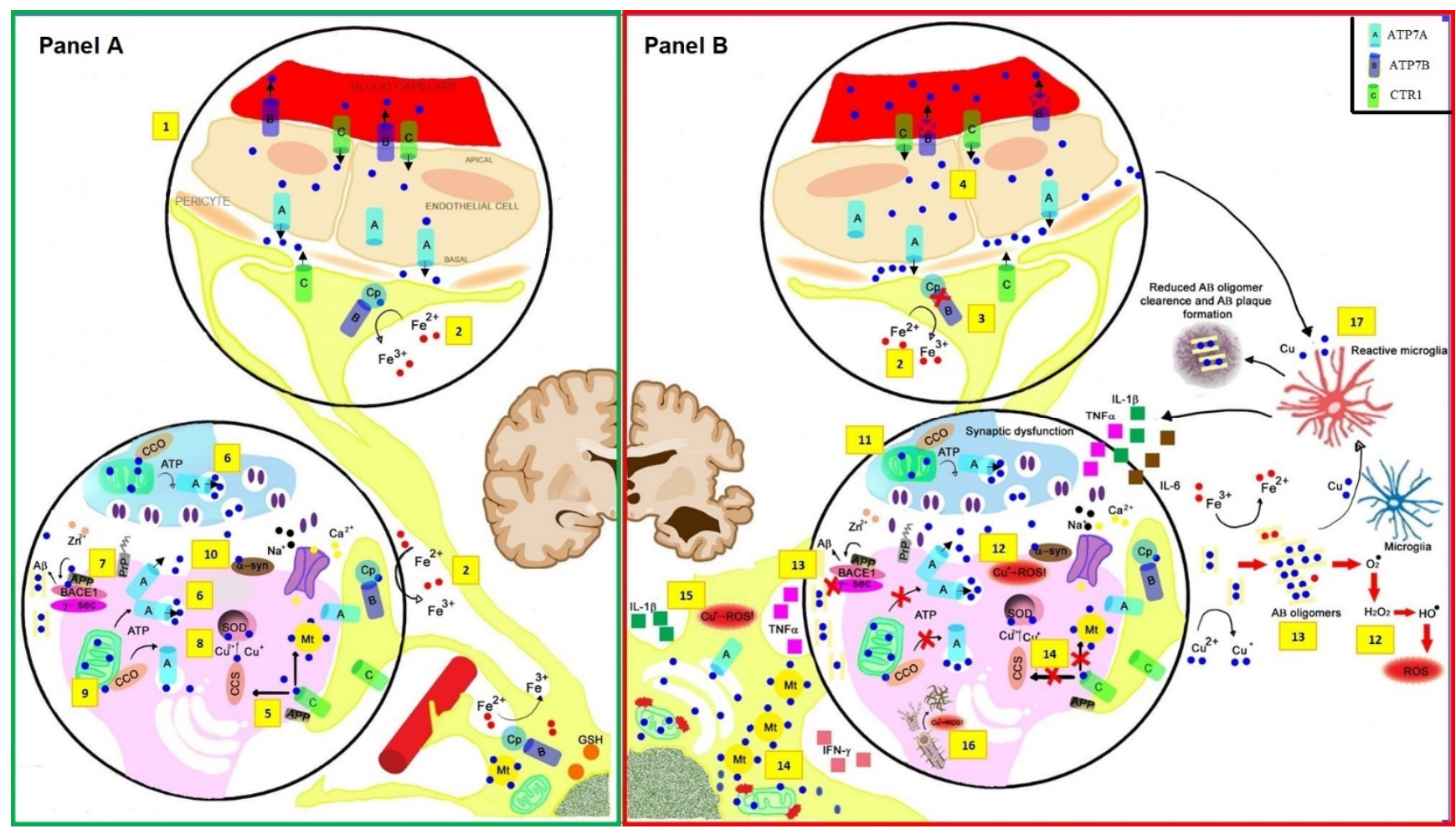

Figure 1. Model of copper $(\mathrm{Cu})$ Physiology ((A) green box, up) and Pathology ((B) red box) in critical areas of the brain related to Alzheimer's disease (AD). At the apposition of the endothelial cells composing the blood-brain barrier (BBB) and the astrocyte foot (1) Cu-related trafficking is facilitated by the CTR1 transporter (Cu shown as blue circles). The two Cu-pump proteins Cu-transporting P-type ATPase, ATP7A and ATP7B, control the metal extrusion from endothelial cells to the bloodstream (ATP7B) or the interstitial fluid (ATP7A). Inside astrocytic feet, ATP7B also promotes Cu loading into glycosylphosphatidylinositol (GPI)-linked ceruloplasmin (Cp) controlling Fe(II)/Fe(III) oxidation state (2). In the AD brain ((B) red box, up), excess Non- $\mathrm{Cp} \mathrm{Cu}$ in the bloodstream is a source for the buildup of labile $\mathrm{Cu}^{2+}$ in the interstitial space, promoting ATP7A/B translocation of $\mathrm{Cu}^{2+}$ into vesicles of the trans-Golgi network and endoplasmic reticulum (ER). Specific variants of the ATP7B protein (for example, R832 and K952, but additional variants may exist) can negatively impact Cu loading into nascent GPI-Cp facilitating $\mathrm{Cu}$ accumulation inside astrocytic feet (3); mutant ATP7B can also affect Cu export from endothelial cells and contribute to $\mathrm{Cu}$ dysregulation (4). Model of $\mathrm{Cu}$ role at the glutamatergic transmission that occurs in the hippocampus at the pyramidal CA1 synapse ((A) green box, bottom). At the synapse, amyloid precursor protein (APP) can reduce $\mathrm{Cu}(\mathrm{II})$ to $\mathrm{Cu}$ (I) to enable $\mathrm{Cu}$ transporter 1 (CTR1) function (5), and ATP7A/B can facilitate copper translocation into vesicles which can then be released at the synaptic cleft (6). APP/A $\beta$ system aids $\mathrm{Cu}$ transport at the synapses, and, in this model, beta-secretase (BACE1), as well as $\gamma$-secretase control production, of $\mathrm{A} \beta$ and $\mathrm{Cu}$ exposure, leads to increased APP expression, and A $\beta$ monomers protect against $\mathrm{Cu}$ - and iron-induced toxicity, and extracellular Prion protein (PrP), $\alpha$-synuclein, and APP can buffer $\mathrm{Cu}(\mathrm{II})$ within the synaptic space, where it can reach high concentrations (100-250 $\mu \mathrm{mol} / \mathrm{L})(7)$. CTR1 transfers $\mathrm{Cu}(\mathrm{I})$ to copper-chaperone for SOD1 (CCS) and metallothionein's (MTs) and CCS transfers $\mathrm{Cu}(\mathrm{I})$ to SOD1 (8). The catalytic reduction of molecular oxygen $\left(\mathrm{O}_{2}\right)$ to water $\left(\mathrm{H}_{2} \mathrm{O}\right)$ by cytochrome c oxidase $(\mathrm{CCO})$ generates the electrical gradient used by mitochondria to create ATP (9). At the glutamatergic synaptic cleft, $\mathrm{Cu}(\mathrm{II})$ is released in a 'free' form either from presynaptic vesicles during transmission in a recycling process regulated by PrP or from the postsynaptic terminal upon stimulation of the N-methyl-D-aspartate (NMDA) receptor downregulating the NMDA receptor activity (10). In the AD brain ((B) red box, bottom), disruption of APP/A $\beta$ system Cu transport may not restrain high $\mathrm{Cu}$ concentration. In turn, ROS-driven $\mathrm{Cu}^{2+}$ mobilization can aggravate oxidative stress and initiate $\mathrm{A} \beta$ oligomerization (13). Furthermore, ROS can mobilize $\mathrm{Cu}^{2+}$ from MT-3 (14), leading to increased intracellular toxic $\mathrm{Cu}^{2+}$ concentrations and mitochondrial dysfunction. Astrocyte activation occurs with release of interleukins (IL) (15). Cu reacts with tau protein contributing to neurofibrillary tangles formation via ROS production (16). $\mathrm{Cu}$ and ROS activate microglia that changes to reactive microglia phenotype and release IL (17). Calcium, $\mathrm{Ca}^{2+}$; Copper, $\mathrm{Cu}$; Iron, $\mathrm{Fe} ; \mathrm{H}_{2} \mathrm{O}_{2}$, hydrogen peroxide; Metallothionein, Mt; $\mathrm{Cu} / \mathrm{Zn}$ superoxide dismutase, SOD1; Sodium, Na+; $\gamma$-secretase, $\gamma$-sec; $\alpha$-synuclein, $\alpha$-syn, Zinc, Zn.

One would predict that restoring $\mathrm{Cu}$ physiology may be beneficial for AD in terms of the delay of disease progression by improving glial functioning, though this needs to be 
clinically tested. Although this review reports a number of processes of glial involvement in $\mathrm{AD}$, the role of microglia and reactive astrogliosis in response to $\mathrm{Cu}$ toxicity is still enigmatic [216]. Knowledge on the labile $\mathrm{Cu}-\mathrm{glia}-\mathrm{AD}$ axis is still in its infancy, and further investigation is needed to determine the pathways of all players in this promising field of research.

Author Contributions: Conceptualization, formal analysis, investigation, and revision-A.P. (Amit Pal) and R.S. writing - original draft preparation, editing, and visualization-I.R., A.P. (Amit Pal), A.P. (Anil Pawar) and M.P. supervision and resources-R.S. and M.R. All authors have read and agreed to the published version of the manuscript.

Funding: This research received no external funding.

Institutional Review Board Statement: Not applicable.

Informed Consent Statement: Not applicable.

Data Availability Statement: Not applicable.

Acknowledgments: The authors thank Elisa Bordignon for figure preparation and assistance.

Conflicts of Interest: R.S. is a Chief Scientific Officer and owns shares at IGEA Pharma N.V. The other authors declare no commercial or noncommercial conflicts of interest related to this work.

\section{References}

1. Henstridge, C.M.; Hyman, B.T.; Spires-Jones, T.L. Beyond the neuron-cellular interactions early in Alzheimer disease pathogenesis. Nat. Rev. Neurosci. 2019, 20, 94-108. [CrossRef] [PubMed]

2. De Strooper, B.; Karran, E. The Cellular Phase of Alzheimer's Disease. Cell 2016, 164, 603-615. [CrossRef]

3. Gibbs, M.E.; Hutchinson, D.; Hertz, L. Astrocytic involvement in learning and memory consolidation. Neurosci. Biobehav. Rev. 2008, 32, 927-944. [CrossRef]

4. Li, B.; Xia, M.; Zorec, R.; Parpura, V.; Verkhratsky, A. Astrocytes in heavy metal neurotoxicity and neurodegeneration. Brain Res. 2021, 1752, 147234. [CrossRef] [PubMed]

5. Pal, A.; Prasad, R. Recent discoveries on the functions of astrocytes in the copper homeostasis of the brain: A brief update. Neurotox. Res. 2014, 26, 78-84. [CrossRef]

6. Streit, W.J.; Khoshbouei, H.; Bechmann, I. The Role of Microglia in Sporadic Alzheimer's Disease. J. Alzheimers Dis. 2021, 79, 961-968. [CrossRef] [PubMed]

7. Von Maydell, D.; Jorfi, M. The interplay between microglial states and major risk factors in Alzheimer's disease through the eyes of single-cell RNA-sequencing: Beyond black and white. J. Neurophysiol. 2019, 122, 1291-1296. [CrossRef]

8. Duggan, M.R.; Parikh, V. Microglia and modifiable life factors: Potential contributions to cognitive resilience in aging. Behav. Brain Res. 2021, 405, 113207. [CrossRef]

9. Sensi, S.L.; Granzotto, A.; Siotto, M.; Squitti, R. Copper and Zinc Dysregulation in Alzheimer's Disease. Trends Pharmacol. Sci. 2018, 39, 1049-1063. [CrossRef]

10. Kierdorf, K.; Masuda, T.; Jordão, M.J.C.; Prinz, M. Macrophages at CNS interfaces: Ontogeny and function in health and disease. Nat. Rev. Neurosci. 2019, 20, 547-562. [CrossRef] [PubMed]

11. Goldmann, T.; Wieghofer, P.; Jordão, M.J.; Prutek, F.; Hagemeyer, N.; Frenzel, K.; Amann, L.; Staszewski, O.; Kierdorf, K.; Krueger, M.; et al. Origin, fate and dynamics of macrophages at central nervous system interfaces. Nat. Immunol. 2016, 17, 797-805. [CrossRef] [PubMed]

12. Cunningham, C.L.; Martínez-Cerdeño, V.; Noctor, S.C. Microglia regulate the number of neural precursor cells in the developing cerebral cortex. J. Neurosci. 2013, 33, 4216-4233. [CrossRef] [PubMed]

13. Ueno, M.; Fujita, Y.; Tanaka, T.; Nakamura, Y.; Kikuta, J.; Ishii, M.; Yamashita, T. Layer V cortical neurons require microglial support for survival during postnatal development. Nat. Neurosci. 2013, 16, 543-551. [CrossRef] [PubMed]

14. Frade, J.M.; Barde, Y.A. Microglia-derived nerve growth factor causes cell death in the developing retina. Neuron 1998, $20,35-41$. [CrossRef]

15. Wilton, D.K.; Dissing-Olesen, L.; Stevens, B. Neuron-Glia Signaling in Synapse Elimination. Annu. Rev. Neurosci. 2019, 42, 107-127. [CrossRef] [PubMed]

16. Filipello, F.; Morini, R.; Corradini, I.; Zerbi, V.; Canzi, A.; Michalski, B.; Erreni, M.; Markicevic, M.; Starvaggi-Cucuzza, C.; Otero, K.; et al. The Microglial Innate Immune Receptor TREM2 Is Required for Synapse Elimination and Normal Brain Connectivity. Immunity 2018, 48, 979-991.e8. [CrossRef] [PubMed]

17. Scott-Hewitt, N.; Perrucci, F.; Morini, R.; Erreni, M.; Mahoney, M.; Witkowska, A.; Carey, A.; Faggiani, E.; Schuetz, L.T.; Mason, S.; et al. Local externalization of phosphatidylserine mediates developmental synaptic pruning by microglia. EMBO J. 2020, 39, e105380. [CrossRef] [PubMed] 
18. Placone, A.L.; McGuiggan, P.M.; Bergles, D.E.; Guerrero-Cazares, H.; Quiñones-Hinojosa, A.; Searson, P.C. Human astrocytes develop physiological morphology and remain quiescent in a novel 3D matrix. Biomaterials 2015, 42, 134-143. [CrossRef]

19. Haseloff, R.F.; Blasig, I.E.; Bauer, H.C.; Bauer, H. In search of the astrocytic factor(s) modulating blood-brain barrier functions in brain capillary endothelial cells in vitro. Cell Mol. Neurobiol. 2005, 25, 25-39. [CrossRef]

20. González-Reyes, R.E.; Nava-Mesa, M.O.; Vargas-Sánchez, K.; Ariza-Salamanca, D.; Mora-Muñoz, L. Involvement of Astrocytes in Alzheimer's Disease from a Neuroinflammatory and Oxidative Stress Perspective. Front. Mol. Neurosci. 2017, 10, 427. [CrossRef] [PubMed]

21. Butovsky, O.; Jedrychowski, M.P.; Moore, C.S.; Cialic, R.; Lanser, A.J.; Gabriely, G.; Koeglsperger, T.; Dake, B.; Wu, P.M.; Doykan, C.E.; et al. Identification of a unique TGF- $\beta$-dependent molecular and functional signature in microglia. Nat. Neurosci. 2014, 17, 131-143, Erratum in: Nat. Neurosci. 2014, 17, 1286. [CrossRef] [PubMed]

22. Holtman, I.R.; Raj, D.D.; Miller, J.A.; Schaafsma, W.; Yin, Z.; Brouwer, N.; Wes, P.D.; Möller, T.; Orre, M.; Kamphuis, W.; et al. Induction of a common microglia gene expression signature by aging and neurodegenerative conditions: A co-expression meta-analysis. Acta Neuropathol. Commun. 2015, 3, 31. [CrossRef] [PubMed]

23. Perry, V.H.; Holmes, C. Microglial priming in neurodegenerative disease. Nat. Rev. Neurol. 2014, 10, 217-224. [CrossRef]

24. Friedman, B.A.; Srinivasan, K.; Ayalon, G.; Meilandt, W.J.; Lin, H.; Huntley, M.A.; Cao, Y.; Lee, S.H.; Haddick, P.C.G.; Ngu, H.; et al. Diverse Brain Myeloid Expression Profiles Reveal Distinct Microglial Activation States and Aspects of Alzheimer's Disease Not Evident in Mouse Models. Cell Rep. 2018, 22, 832-847. [CrossRef]

25. Krasemann, S.; Madore, C.; Cialic, R.; Baufeld, C.; Calcagno, N.; El Fatimy, R.; Beckers, L.; O’Loughlin, E.; Xu, Y.; Fanek, Z.; et al. The TREM2-APOE Pathway Drives the Transcriptional Phenotype of Dysfunctional Microglia in Neurodegenerative Diseases. Immunity 2017, 47, 566-581.e9. [CrossRef] [PubMed]

26. Keren-Shaul, H.; Spinrad, A.; Weiner, A.; Matcovitch-Natan, O.; Dvir-Szternfeld, R.; David, E.; Baruch, K.; Lara-Astaiso, D.; Toth, B.; Itzkovitz, S.; et al. A Unique Microglia Type Associated with Restricting Development of Alzheimer's Disease. Cell 2017, 169, 1276-1290.e17. [CrossRef] [PubMed]

27. Sobue, A.; Komine, O.; Hara, Y.; Endo, F.; Mizoguchi, H.; Watanabe, S.; Murayama, S.; Saito, T.; Saido, T.C.; Sahara, N.; et al. Microglial gene signature reveals loss of homeostatic microglia associated with neurodegeneration of Alzheimer's disease. Acta Neuropathol. Commun. 2021, 9, 1. [CrossRef] [PubMed]

28. Hickman, S.E.; Kingery, N.D.; Ohsumi, T.K.; Borowsky, M.L.; Wang, L.C.; Means, T.K. The microglial sensome revealed by direct RNA sequencing. Nat. Neurosci. 2013, 16, 1896-1905. [CrossRef]

29. Ajami, B.; Samusik, N.; Wieghofer, P.; Ho, P.P.; Crotti, A.; Bjornson, Z. Single-cell mass cytometry reveals distinct populations of brain myeloid cells in mouse neuroinflammation and neurodegeneration models. Nat. Neurosci. 2018, 21, 541-551. [CrossRef]

30. Leyns, C.E.G.; Ulrich, J.D.; Finn, M.B.; Stewart, F.R.; Koscal, L.J.; Remolina Serrano, J.; Robinson, G.O.; Anderson, E.; Colonna, M.; Holtzman, D.M. TREM2 deficiency attenuates neuroinflammation and protects against neurodegeneration in a mouse model of tauopathy. Proc. Natl. Acad. Sci. USA 2017, 114, 11524-11529. [CrossRef]

31. Mrdjen, D.; Pavlovic, A.; Hartmann, F.J.; Schreiner, B.; Utz, S.G.; Leung, B.P.; Lelios, I.; Heppner, F.L.; Kipnis, J.; Merkler, D.; et al. High-Dimensional Single-Cell Mapping of Central Nervous System Immune Cells Reveals Distinct Myeloid Subsets in Health, Aging, and Disease. Immunity 2018, 48, 380-395.e6, Erratum in: Immunity 2018, 48, 599. [CrossRef] [PubMed]

32. Yu, Y.; Ye, R.D. Microglial A $\beta$ Receptors in Alzheimer's Disease. Cell Mol. Neurobiol. 2015, 35, 71-83. [CrossRef] [PubMed]

33. Mazaheri, F.; Snaidero, N.; Kleinberger, G.; Madore, C.; Daria, A.; Werner, G.; Krasemann, S.; Capell, A.; Trümbach, D.; Wurst, W.; et al. TREM2 deficiency impairs chemotaxis and microglial responses to neuronal injury. EMBO Rep. 2017, 18, 1186-1198. [CrossRef] [PubMed]

34. Jay, T.R.; Hirsch, A.M.; Broihier, M.L.; Miller, C.M.; Neilson, L.E.; Ransohoff, R.M.; Lamb, B.T.; Landreth, G.E. Disease ProgressionDependent Effects of TREM2 Deficiency in a Mouse Model of Alzheimer's Disease. J. Neurosci. 2017, 37, 637-647. [CrossRef]

35. Hopp, S.C.; Lin, Y.; Oakley, D.; Roe, A.D.; DeVos, S.L.; Hanlon, D.; Hyman, B.T. The role of microglia in processing and spreading of bioactive tau seeds in Alzheimer's disease. J. Neuroinflamm. 2018, 15, 269. [CrossRef]

36. Gratuze, M.; Chen, Y.; Parhizkar, S.; Jain, N.; Strickland, M.R.; Serrano, J.R.; Colonna, M.; Ulrich, J.D.; Holtzman, D.M. Activated microglia mitigate A $\beta$-associated tau seeding and spreading. J. Exp. Med. 2021, 218, e20210542. [CrossRef] [PubMed]

37. Hansen, D.V.; Hanson, J.E.; Sheng, M. Microglia in Alzheimer's disease. J. Cell Biol. 2018, 217, 459-472. [CrossRef] [PubMed]

38. Shi, Q.; Chowdhury, S.; Ma, R.; Le, K.X.; Hong, S.; Caldarone, B.J.; Stevens, B.; Lemere, C.A. Complement C3 deficiency protects against neurodegeneration in aged plaque-rich APP/PS1 mice. Sci. Transl. Med. 2017, 9, eaaf6295. [CrossRef]

39. Wu, T.; Dejanovic, B.; Gandham, V.D.; Gogineni, A.; Edmonds, R.; Schauer, S.; Srinivasan, K.; Huntley, M.A.; Wang, Y.; Wang, T.M.; et al. Complement C3 Is Activated in Human AD Brain and Is Required for Neurodegeneration in Mouse Models of Amyloidosis and Tauopathy. Cell Rep. 2019, 28, 2111-2123. [CrossRef]

40. Dejanovic, B.; Huntley, M.A.; De Mazière, A.; Meilandt, W.J.; Wu, T.; Srinivasan, K.; Jiang, Z.; Gandham, V.; Friedman, B.A.; Ngu, H.; et al. Changes in the Synaptic Proteome in Tauopathy and Rescue of Tau-Induced Synapse Loss by C1q Antibodies. Neuron 2018, 100, 1322-1336. [CrossRef]

41. Zhang, D.; Hu, X.; Qian, L.; Chen, S.H.; Zhou, H.; Wilson, B.; Miller, D.S.; Hong, J.S. Microglial MAC1 receptor and PI3K are essential in mediating $\beta$-amyloid peptide-induced microglial activation and subsequent neurotoxicity. J. Neuroinflamm. 2011, 8, 3. [CrossRef] [PubMed] 
42. Terwel, D.; Steffensen, K.R.; Verghese, P.B.; Kummer, M.P.; Gustafsson, J.A.; Holtzman, D.M.; Heneka, M.T. Critical role of astroglial apolipoprotein $\mathrm{E}$ and liver $\mathrm{X}$ receptor- $\alpha$ expression for microglial A $\beta$ phagocytosis. J. Neurosci. 2011, 31, 7049-7059. [CrossRef] [PubMed]

43. Yeh, F.L.; Wang, Y.; Tom, I.; Gonzalez, L.C.; Sheng, M. TREM2 Binds to Apolipoproteins, Including APOE and CLU/APOJ, and Thereby Facilitates Uptake of Amyloid-Beta by Microglia. Neuron 2016, 91, 328-340. [CrossRef]

44. Lee, C.Y.; Landreth, G.E. The role of microglia in amyloid clearance from the AD brain. J. Neural Transm. 2010, 117, 949-960. [CrossRef] [PubMed]

45. Jendresen, C.; Digre, A.; Cui, H.; Zhang, X.; Vlodavsky, I.; Li, J.P.; Nilsson, L.N.G. Systemic LPS-induced A $\beta$-solubilization and clearance in A $\beta$ PP-transgenic mice is diminished by heparanase overexpression. Sci. Rep. 2019, 9, 4600. [CrossRef]

46. Kitazawa, M.; Oddo, S.; Yamasaki, T.R.; Green, K.N.; LaFerla, F.M. Lipopolysaccharide-induced inflammation exacerbates tau pathology by a cyclin-dependent kinase 5-mediated pathway in a transgenic model of Alzheimer's disease. J. Neurosci. 2005, 25, 8843-8853. [CrossRef]

47. Lee, D.C.; Rizer, J.; Selenica, M.L.; Reid, P.; Kraft, C.; Johnson, A.; Blair, L.; Gordon, M.N.; Dickey, C.A.; Morgan, D. LPS- induced inflammation exacerbates phospho-tau pathology in rTg4510 mice. J. Neuroinflamm. 2010, 7, 56. [CrossRef]

48. Zhan, X.; Stamova, B.; Jin, L.W.; DeCarli, C.; Phinney, B.; Sharp, F.R. Gram-negative bacterial molecules associate with Alzheimer disease pathology. Neurology 2016, 87, 2324-2332. [CrossRef]

49. Zhao, Y.; Cong, L.; Jaber, V.; Lukiw, W.J. Microbiome-Derived Lipopolysaccharide Enriched in the Perinuclear Region of Alzheimer's Disease Brain. Front. Immunol. 2017, 8, 1064. [CrossRef]

50. Nakanishi, H. Microglial cathepsin B as a key driver of inflammatory brain diseases and brain aging. Neural Regen. Res. 2020, 15, 25-29. [CrossRef]

51. Zamanian, J.L.; Xu, L.; Foo, L.C.; Nouri, N.; Zhou, L.; Giffard, R.G.; Barres, B.A. Genomic analysis of reactive astrogliosis. J. Neurosci. 2012, 32, 6391-6410. [CrossRef] [PubMed]

52. Sakakibara, Y.; Sekiya, M.; Saito, T.; Saido, T.C.; Iijima, K.M. Amyloid- $\beta$ plaque formation and reactive gliosis are required for induction of cognitive deficits in App knock-in mouse models of Alzheimer's disease. BMC Neurosci. 2019, 20, 13. [CrossRef] [PubMed]

53. Liddelow, S.A.; Guttenplan, K.A.; Clarke, L.E.; Bennett, F.C.; Bohlen, C.J.; Schirmer, L.; Bennett, M.L.; Münch, A.E.; Chung, W.S.; Peterson, T.C.; et al. Neurotoxic reactive astrocytes are induced by activated microglia. Nature 2017, 541, 481-487. [CrossRef]

54. Ries, M.; Sastre, M. Mechanisms of A $\beta$ Clearance and Degradation by Glial Cells. Front. Aging Neurosci. 2016, 8, 160. [CrossRef] [PubMed]

55. Joly-Amado, A.; Hunter, J.; Quadri, Z.; Zamudio, F.; Rocha-Rangel, P.V.; Chan, D.; Kesarwani, A.; Nash, K.; Lee, D.C.; Morgan, D.; et al. CCL2 Overexpression in the Brain Promotes Glial Activation and Accelerates Tau Pathology in a Mouse Model of Tauopathy. Front. Immunol. 2020, 11, 997. [CrossRef]

56. Urrutia, P.J.; Hirsch, E.C.; González-Billault, C.; Núñez, M.T. Hepcidin attenuates amyloid beta-induced inflammatory and pro-oxidant responses in astrocytes and microglia. J. Neurochem. 2017, 142, 140-152. [CrossRef]

57. Haghighatseir, N.; Ashrafi, H.; Rafiei, P.; Azadi, A. Dexamethasone ameliorates Alzheimer's pathological condition via inhibiting Nf-kappa B and mTOR signaling pathways. Biointerface Res. Appl. Chem. 2020, 10, 5792-5796.

58. Lian, H.; Litvinchuk, A.; Chiang, A.C.; Aithmitti, N.; Jankowsky, J.L.; Zheng, H. Astrocyte-Microglia Cross Talk through Complement Activation Modulates Amyloid Pathology in Mouse Models of Alzheimer's Disease. J. Neurosci. 2016, 36, 577-589. [CrossRef]

59. Esshili, A.; Manitz, M.P.; Freund, N.; Juckel, G. Induction of inducible nitric oxide synthase expression in activated microglia and astrocytes following pre- and postnatal immune challenge in an animal model of schizophrenia. Eur. Neuropsychopharmacol. 2020, 35, 100-110. [CrossRef] [PubMed]

60. Lesné, S.; Docagne, F.; Gabriel, C.; Liot, G.; Lahiri, D.K.; Buée, L.; Plawinski, L.; Delacourte, A.; MacKenzie, E.T.; Buisson, A.; et al. Transforming growth factor-beta 1 potentiates amyloid-beta generation in astrocytes and in transgenic mice. J. Biol. Chem. 2003, 278, 18408-18418. [CrossRef]

61. Zhao, J.; O'Connor, T.; Vassar, R. The contribution of activated astrocytes to A $\beta$ production: Implications for Alzheimer's disease pathogenesis. J. Neuroinflamm. 2011, 8, 150. [CrossRef]

62. Blasko, I.; Veerhuis, R.; Stampfer-Kountchev, M.; Saurwein-Teissl, M.; Eikelenboom, P.; Grubeck-Loebenstein, B. Costimulatory effects of interferon-gamma and interleukin-1beta or tumor necrosis factor alpha on the synthesis of Abeta1-40 and Abeta1-42 by human astrocytes. Neurobiol. Dis. 2000, 7, 682-689. [CrossRef] [PubMed]

63. Söllvander, S.; Nikitidou, E.; Brolin, R.; Söderberg, L.; Sehlin, D.; Lannfelt, L.; Erlandsson, A. Accumulation of amyloid- $\beta$ by astrocytes result in enlarged endosomes and microvesicle-induced apoptosis of neurons. Mol. Neurodegener. 2016, 11, 38. [CrossRef] [PubMed]

64. Liang, Y.; Raven, F.; Ward, J.F.; Zhen, S.; Zhang, S.; Sun, H.; Miller, S.J.; Choi, S.H.; Tanzi, R.E.; Zhang, C. Upregulation of Alzheimer's Disease Amyloid- $\beta$ Protein Precursor in Astrocytes Both in vitro and in vivo. J. Alzheimers Dis. 2020, 76, 1071-1082. [CrossRef] [PubMed]

65. Taylor, X.; Cisternas, P.; You, Y.; You, Y.; Xiang, S.; Marambio, A.; Zhang, J.; Vidal, R.; Lasagna-Reeves, C.A. A1 reactive astrocytes and a loss of TREM2 are associated with an early stage of pathology in a mouse model of cerebral amyloid angiopathy. $J$. Neuroinflamm. 2020, 17, 223. [CrossRef] 
66. Carter, S.F.; Schöll, M.; Almkvist, O.; Wall, A.; Engler, H.; Långström, B.; Nordberg, A. Evidence for astrocytosis in prodromal Alzheimer disease provided by 11C-deuterium-L-deprenyl: A multitracer PET paradigm combining 11C-Pittsburgh compound B and 18F-FDG. J. Nucl. Med. 2012, 53, 37-46. [CrossRef] [PubMed]

67. Sofroniew, M.V.; Vinters, H.V. Astrocytes: Biology and pathology. Acta Neuropathol. 2010, 119, 7-35. [CrossRef] [PubMed]

68. Yamamoto, N.; Nakazawa, M.; Nunono, N.; Yoshida, N.; Obuchi, A.; Tanida, M.; Suzuki, K.; Ikeda-Matsuo, Y.; Sobue, K. Protein kinases $A$ and $C$ regulate amyloid- $\beta$ degradation by modulating protein levels of neprilysin and insulin-degrading enzyme in astrocytes. Neurosci. Res. 2021, 166, 62-72. [CrossRef] [PubMed]

69. Davis, N.; Mota, B.C.; Stead, L.; Palmer, E.O.C.; Lombardero, L.; Rodríguez-Puertas, R.; de Paola, V.; Barnes, S.J.; Sastre, M. Pharmacological ablation of astrocytes reduces A $\beta$ degradation and synaptic connectivity in an ex vivo model of Alzheimer's disease. J. Neuroinflamm. 2021, 18, 73. [CrossRef] [PubMed]

70. Liu, C.C.; Hu, J.; Zhao, N.; Wang, J.; Wang, N.; Cirrito, J.R.; Kanekiyo, T.; Holtzman, D.M.; Bu, G. Astrocytic LRP1 Mediates Brain A $\beta$ Clearance and Impacts Amyloid Deposition. J. Neurosci. 2017, 37, 4023-4031. [CrossRef] [PubMed]

71. Palmer, J.C.; Baig, S.; Kehoe, P.G.; Love, S. Endothelin-converting enzyme-2 is increased in Alzheimer's disease and up-regulated by Abeta. Am. J. Pathol. 2009, 175, 262-270. [CrossRef] [PubMed]

72. Lanfranco, M.F.; Sepulveda, J.; Kopetsky, G.; Rebeck, G.W. Expression and secretion of apoE isoforms in astrocytes and microglia during inflammation. Glia 2021, 69, 1478-1493. [CrossRef]

73. Chen, F.; Swartzlander, D.B.; Ghosh, A.; Fryer, J.D.; Wang, B.; Zheng, H. Clusterin secreted from astrocyte promotes excitatory synaptic transmission and ameliorates Alzheimer's disease neuropathology. Mol. Neurodegener. 2021, 16, 5. [CrossRef] [PubMed]

74. Ebrahimi, T.; Rust, M.; Kaiser, S.N.; Slowik, A.; Beyer, C.; Koczulla, A.R.; Schulz, J.B.; Habib, P.; Bach, J.P. $\alpha 1$-antitrypsin mitigates NLRP3-inflammasome activation in amyloid $\beta_{1-42}$-stimulated murine astrocytes. J. Neuroinflamm. 2018, 15, 282. [CrossRef]

75. Pertusa, M.; García-Matas, S.; Mammeri, H.; Adell, A.; Rodrigo, T.; Mallet, J.; Cristòfol, R.; Sarkis, C.; Sanfeliu, C. Expression of GDNF transgene in astrocytes improves cognitive deficits in aged rats. Neurobiol. Aging 2008, 29, 1366-1379. [CrossRef] [PubMed]

76. Sáez, E.T.; Pehar, M.; Vargas, M.R.; Barbeito, L.; Maccioni, R.B. Production of nerve growth factor by beta-amyloid-stimulated astrocytes induces p75NTR-dependent tau hyperphosphorylation in cultured hippocampal neurons. J. Neurosci. Res. 2006, 84, 1098-1106. [CrossRef] [PubMed]

77. Li, T.; Liu, T.; Chen, X.; Li, L.; Feng, M.; Zhang, Y.; Wan, L.; Zhang, C.; Yao, W. Microglia induce the transformation of A1/A2 reactive astrocytes via the CXCR7/PI3K/Akt pathway in chronic post-surgical pain. J. Neuroinflamm. 2020, 17, 211. [CrossRef] [PubMed]

78. Monnet-Tschudi, F.; Zurich, M.G.; Boschat, C.; Corbaz, A.; Honegger, P. Involvement of environmental mercury and lead in the etiology of neurodegenerative diseases. Rev. Environ. Health 2006, 21, 105-117. [CrossRef]

79. Squitti, R. Copper dysfunction in Alzheimer's disease: From meta-analysis of biochemical studies to new insight into genetics. J. Trace Elem. Med. Biol. 2012, 26, 93-96. [CrossRef]

80. Brewer, G.J. Divalent Copper as a Major Triggering Agent in Alzheimer's Disease. J. Alzheimers Dis. 2015, 46, 593-604. [CrossRef] [PubMed]

81. Squitti, R.; Polimanti, R.; Bucossi, S.; Ventriglia, M.; Mariani, S.; Manfellotto, D.; Vernieri, F.; Cassetta, E.; Ursini, F.; Rossini, P.M. Linkage disequilibrium and haplotype analysis of the ATP7B gene in Alzheimer's disease. Rejuvenation Res. 2013, 16, 3-10. [CrossRef] [PubMed]

82. Siotto, M.; Squitti, R. Copper imbalance in Alzheimer's disease: Overview of the exchangeable copper component in plasma and the intriguing role albumin plays. Coord. Chem. Rev. 2018, 371, 86-95. [CrossRef]

83. Kepp, K.P.; Squitti, R. Copper imbalance in Alzheimer's disease: Convergence of the chemistry and the clinic. Coord. Chem. Rev. 2019, 397, 168-187. [CrossRef]

84. Squitti, R.; Faller, P.; Hureau, C.; Granzotto, A.; White, A.R.; Kepp, K.P. Copper Imbalance in Alzheimer's Disease and Its Link with the Amyloid Hypothesis: Towards a Combined Clinical, Chemical, and Genetic Etiology. J. Alzheimers Dis. 2021, 83, $23-41$. [CrossRef]

85. Everett, J.; Lermyte, F.; Brooks, J.; Tjendana-Tjhin, V.; Plascencia-Villa, G.; Hands-Portman, I.; Donnelly, J.M.; Billimoria, K.; Perry, G.; Zhu, X.; et al. Biogenic metallic elements in the human brain? Sci. Adv. 2021, 7, eabf6707. [CrossRef]

86. Silbert, L.C.; Lahna, D.; Promjunyakul, N.O.; Boespflug, E.; Ohya, Y.; Higashiuesato, Y.; Nishihira, J.; Katsumata, Y.; Tokashiki, T.; Dodge, H.H. Risk Factors Associated with Cortical Thickness and White Matter Hyperintensities in Dementia Free Okinawan Elderly. J. Alzheimers Dis. 2018, 63, 365-372. [CrossRef]

87. Talwar, P.; Grover, S.; Sinha, J.; Chandna, P.; Agarwal, R.; Kushwaha, S.; Kukreti, R. Multifactorial Analysis of a Biomarker Pool for Alzheimer Disease Risk in a North Indian Population. Dement. Geriatr. Cogn. Disord. 2017, 44, 25-34. [CrossRef]

88. Wang, Z.X.; Tan, L.; Wang, H.F.; Ma, J.; Liu, J.; Tan, M.S.; Sun, J.H.; Zhu, X.C.; Jiang, T.; Yu, J.T. Serum Iron, Zinc, and Copper Levels in Patients with Alzheimer's Disease: A Replication Study and Meta-Analyses. J. Alzheimers Dis. 2015, 47, 565-581. [CrossRef]

89. Sparks, D.L.; Schreurs, B.G. Trace amounts of copper in water induce beta-amyloid plaques and learning deficits in a rabbit model of Alzheimer's disease. Proc. Natl. Acad. Sci. USA 2003, 100, 11065-11069. [CrossRef]

90. Hsu, H.W.; Rodriguez-Ortiz, C.J.; Lim, S.L.; Zumkehr, J.; Kilian, J.G.; Vidal, J. Copper-Induced Upregulation of MicroRNAs Directs the Suppression of Endothelial LRP1 in Alzheimer's Disease Model. Toxicol. Sci. 2019, 170, 144-156. [CrossRef] 
91. Singh, I.; Sagare, A.P.; Coma, M.; Perlmutter, D.; Gelein, R.; Bell, R.D.; Deane, R.J.; Zhong, E.; Parisi, M.; Ciszewski, J.; et al. Low levels of copper disrupt brain amyloid- $\beta$ homeostasis by altering its production and clearance. Proc. Natl. Acad. Sci. USA 2013, 110, 14771-14776. [CrossRef]

92. Pal, A.; Prasad, R. An overview of various mammalian models to study chronic copper intoxication associated Alzheimer's disease like pathology. Biometals 2015, 28, 1-9. [CrossRef]

93. Arnal, N.; Castillo, O.; de Alaniz, M.J.; Marra, C.A. Effects of Copper and/or Cholesterol Overload on Mitochondrial Function in a Rat Model of Incipient Neurodegeneration. Int. J. Alzheimers Dis. 2013, 2013, 645379. [CrossRef]

94. Squitti, R.; Simonelli, I.; Ventriglia, M.; Siotto, M.; Pasqualetti, P.; Rembach, A.; Doecke, J.; Bush, A.I. Meta-analysis of serum non-ceruloplasmin copper in Alzheimer's disease. J. Alzheimers Dis. 2014, 38, 809-822. [CrossRef]

95. Squitti, R.; Ventriglia, M.; Gennarelli, M.; Colabufo, N.A.; El Idrissi, I.G.; Bucossi, S.; Mariani, S.; Rongioletti, M.; Zanetti, O.; Congiu, C.; et al. Non-Ceruloplasmin Copper Distincts Subtypes in Alzheimer's Disease: A Genetic Study of ATP7B Frequency. Mol. Neurobiol. 2017, 54, 671-681. [CrossRef]

96. James, S.A.; Volitakis, I.; Adlard, P.A.; Duce, J.A.; Masters, C.L.; Cherny, R.A.; Bush, A.I. Elevated labile Cu is associated with oxidative pathology in Alzheimer disease. Free Radic. Biol. Med. 2012, 52, 298-302. [CrossRef]

97. Ma, Q.; Ying, M.; Sui, X.; Zhang, H.; Huang, H.; Yang, L.; Huang, X.; Zhuang, Z.; Liu, J.; Yang, X. Chronic copper exposure causes spatial memory impairment, selective loss of hippocampal synaptic proteins, and activation of PKR/eIF2 $\alpha$ pathway in mice. $J$. Alzheimers Dis. 2015, 43, 1413-1427. [CrossRef]

98. Jomova, K.; Vondrakova, D.; Lawson, M.; Valko, M. Metals, oxidative stress and neurodegenerative disorders. Mol. Cell Biochem. 2010, 345, 91-104. [CrossRef]

99. Sutton, H.C.; Winterbourn, C.C. On the participation of higher oxidation states of iron and copper in Fenton reactions. Free Radic. Biol. Med. 1989, 6, 53-60. [CrossRef]

100. Christen, Y. Oxidative stress and Alzheimer disease. Am. J. Clin. Nutr. 2000, 71, 621S-629S. [CrossRef]

101. Gorni, D.; Finco, A. Oxidative stress in elderly population: A prevention screening study. Aging Med. 2020, 3, 205-213. [CrossRef]

102. Rai, R.K.; Chalana, A.; Karri, R.; Das, R.; Kumar, B.; Roy, G. Role of Hydrogen Bonding by Thiones in Protecting Biomolecules from Copper(I)-Mediated Oxidative Damage. Inorg. Chem. 2019, 58, 6628-6638. [CrossRef]

103. Galeazzi, L.; Ronchi, P.; Franceschi, C.; Giunta, S. In vitro peroxidase oxidation induces stable dimers of beta-amyloid (1-42) through dityrosine bridge formation. Amyloid 1999, 6, 7-13. [CrossRef]

104. Hureau, C.; Faller, P. Abeta-mediated ROS production by Cu ions: Structural insights, mechanisms and relevance to Alzheimer's disease. Biochimie 2019, 91, 1212-1217. [CrossRef]

105. Speisky, H.; Gómez, M.; Burgos-Bravo, F. Generation of superoxide radicals by copper-glutathione complexes: Redoxconsequences associated with their interaction with reduced glutathione. Bioorg. Med. Chem. 2009, 17, 1803-1810. [CrossRef]

106. Jiang, X.; Stockwell, B.R.; Conrad, M. Ferroptosis: Mechanisms, biology and role in disease. Nat. Rev. Mol. Cell Biol. 2021, 22, 266-282. [CrossRef]

107. Ayton, S.; Portbury, S.; Kalinowski, P.; Agarwal, P.; Diouf, I.; Schneider, J.A.; Morris, M.C.; Ashley, I.A. Regional brain iron associated with deterioration in Alzheimer's disease: A large cohort study and theoretical significance. Alzheimers Dement. 2021, 17, 1244-1256. [CrossRef]

108. Myhre, O.; Utkilen, H.; Duale, N.; Brunborg, G.; Hofer, T. Metal dyshomeostasis and inflammation in Alzheimer's and Parkinson's diseases: Possible impact of environmental exposures. Oxid. Med. Cell Longev. 2013, 2013, 726954. [CrossRef]

109. Yu, H.; Jiang, X.; Lin, X.; Zhang, Z.; Wu, D.; Zhou, L.; Liu, J.; Yang, X. Hippocampal Subcellular Organelle Proteomic Alteration of Copper-Treated Mice. Toxicol. Sci. 2018, 164, 250-263. [CrossRef]

110. Choo, X.Y.; Alukaidey, L.; White, A.R.; Grubman, A. Neuroinflammation and copper in Alzheimer's disease. Int. J. Alzheimers Dis. 2013, 2013, 145345. [CrossRef]

111. Cottrell, D.A.; Blakely, E.L.; Johnson, M.A.; Ince, P.G.; Turnbull, D.M. Mitochondrial enzyme-deficient hippocampal neurons and choroidal cells in AD. Neurology 2001, 57, 260-264. [CrossRef] [PubMed]

112. Davis, R.E.; Miller, S.; Herrnstadt, C.; Ghosh, S.S.; Fahy, E.; Shinobu, L.A.; Galasko, D.; Thal, L.J.; Beal, M.F.; Howell, N.; et al. Mutations in mitochondrial cytochrome c oxidase genes segregate with late-onset Alzheimer disease. Proc. Natl. Acad. Sci. USA 1997, 94, 4526-4531. [CrossRef] [PubMed]

113. Omar, R.A.; Chyan, Y.J.; Andorn, A.C.; Poeggeler, B.; Robakis, N.K.; Pappolla, M.A. Increased Expression but Reduced Activity of Antioxidant Enzymes in Alzheimer's Disease. J. Alzheimers Dis. 1999, 1, 139-145. [CrossRef] [PubMed]

114. Bayer, T.A.; Schäfer, S.; Simons, A.; Kemmling, A.; Kamer, T.; Tepest, R.; Eckert, A.; Schüssel, K.; Eikenberg, O.; Sturchler-Pierrat, C.; et al. Dietary Cu stabilizes brain superoxide dismutase 1 activity and reduces amyloid Abeta production in APP23 transgenic mice. Proc. Natl. Acad. Sci. USA 2003, 100, 14187-14192. [CrossRef]

115. Connor, J.R.; Tucker, P.; Johnson, M.; Snyder, B. Ceruloplasmin levels in the human superior temporal gyrus in aging and Alzheimer's disease. Neurosci. Lett. 1993, 159, 88-90. [CrossRef]

116. Samokyszyn, V.M.; Reif, D.W.; Miller, D.M.; Aust, S.D. Effects of ceruloplasmin on superoxide-dependent iron release from ferritin and lipid peroxidation. Free Radic. Res. Commun. 1991, 1, 153-159. [CrossRef]

117. Rossi, L.; Lombardo, M.F.; Ciriolo, M.R.; Rotilio, G. Mitochondrial dysfunction in neurodegenerative diseases associated with copper imbalance. Neurochem. Res. 2004, 29, 493-504. [CrossRef] [PubMed] 
118. Solomon, E.I.; Heppner, D.E.; Johnston, E.M.; Ginsbach, J.W.; Cirera, J.; Qayyum, M.; Kieber-Emmons, M.T.; Kjaergaard, C.H.; Hadt, R.G.; Tian, L. Copper active sites in biology. Chem. Rev. 2014, 114, 3659-3853. [CrossRef] [PubMed]

119. Glerum, D.M.; Shtanko, A.; Tzagoloff, A. Characterization of COX17, a yeast gene involved in copper metabolism and assembly of cytochrome oxidase. J. Biol. Chem. 1996, 271, 14504-14509. [CrossRef]

120. Rossi, L.; Lippe, G.; Marchese, E.; De Martino, A.; Mavelli, I.; Rotilio, G.; Ciriolo, M.R. Decrease of cytochrome c oxidase protein in heart mitochondria of copper-deficient rats. Biometals 1998, 11, 207-212. [CrossRef]

121. Carvalho, C.; Correia, S.C.; Santos, R.X.; Cardoso, S.; Moreira, P.I.; Clark, T.A.; Zhu, X.; Smith, M.A.; Perry, G. Role of mitochondrialmediated signaling pathways in Alzheimer disease and hypoxia. J. Bioenerg. Biomembr. 2009, 41, 433-440. [CrossRef] [PubMed]

122. Kobayashi, Y.; Amaral, G.D. Chapter IV: Chemical Neuroanatomy of the Hippocampal Formation and the Perirhinal and Parahippocampal Cortices. Handb. Chem. Neuroanat. 1999, 15, 285-401. [CrossRef]

123. Adav, S.S.; Park, J.E.; Sze, S.K. Quantitative profiling brain proteomes revealed mitochondrial dysfunction in Alzheimer's disease. Mol. Brain 2019, 12, 8. [CrossRef]

124. Maurer, I.; Zierz, S.; Möller, H.J. A selective defect of cytochrome c oxidase is present in brain of Alzheimer disease patients. Neurobiol. Aging 2000, 21, 455-462. [CrossRef]

125. Duara, R.; Grady, C.; Haxby, J.; Sundaram, M.; Cutler, N.R.; Heston, L.; Moore, A.; Schlageter, N.; Larson, S.; Rapoport, S.I. Positron emission tomography in Alzheimer's disease. Neurology 1986, 36, 879-887. [CrossRef] [PubMed]

126. McGeer, E.G.; McGeer, P.L.; Harrop, R.; Akiyama, H.; Kamo, H. Correlations of regional postmortem enzyme activities with premortem local glucose metabolic rates in Alzheimer's disease. J. Neurosci. Res. 1990, 27, 612-619. [CrossRef] [PubMed]

127. Mielke, R.; Schröder, R.; Fink, G.R.; Kessler, J.; Herholz, K.; Heiss, W.D. Regional cerebral glucose metabolism and postmortem pathology in Alzheimer's disease. Acta Neuropathol. 1996, 91, 174-179. [CrossRef] [PubMed]

128. Kitazawa, M.; Cheng, D.; Laferla, F.M. Chronic copper exposure exacerbates both amyloid and tau pathology and selectively dysregulates cdk5 in a mouse model of AD. J. Neurochem. 2009, 108, 1550-1560. [CrossRef] [PubMed]

129. Voss, K.; Harris, C.; Ralle, M.; Duffy, M.; Murchison, C.; Quinn, J.F. Modulation of tau phosphorylation by environmental copper. Transl. Neurodegener. 2014, 3, 24. [CrossRef] [PubMed]

130. Maynard, C.J.; Cappai, R.; Volitakis, I.; Cherny, R.A.; White, A.R.; Beyreuther, K.; Masters, C.L.; Bush, A.I.; Li, Q.X. Overexpression of Alzheimer's disease amyloid-beta opposes the age-dependent elevations of brain copper and iron. J. Biol. Chem. 2002, 277, 44670-44676. [CrossRef] [PubMed]

131. Huang, X.; Cuajungco, M.P.; Atwood, C.S.; Hartshorn, M.A.; Tyndall, J.D.; Hanson, G.R.; Stokes, K.C.; Leopold, M.; Multhaup, G.; Goldstein, L.E.; et al. Cu(II) potentiation of alzheimer abeta neurotoxicity. Correlation with cell-free hydrogen peroxide production and metal reduction. J. Biol. Chem. 1999, 274, 37111-37116. [CrossRef] [PubMed]

132. Smith, D.P.; Ciccotosto, G.D.; Tew, D.J.; Fodero-Tavoletti, M.T.; Johanssen, T.; Masters, C.L.; Barnham, K.J.; Cappai, R. Concentration dependent $\mathrm{Cu}^{2+}$ induced aggregation and dityrosine formation of the Alzheimer's disease amyloid-beta peptide. Biochemistry 2007, 46, 2881-2891. [CrossRef]

133. Tõugu, V.; Karafin, A.; Zovo, K.; Chung, R.S.; Howells, C.; West, A.K.; Palumaa, P. Zn(II)- and Cu(II)-induced non-fibrillar aggregates of amyloid-beta (1-42) peptide are transformed to amyloid fibrils, both spontaneously and under the influence of metal chelators. J. Neurochem. 2009, 110, 1784-1795. [CrossRef] [PubMed]

134. Sarell, C.J.; Syme, C.D.; Rigby, S.E.; Viles, J.H. Copper(II) binding to amyloid-beta fibrils of Alzheimer's disease reveals a picomolar affinity: Stoichiometry and coordination geometry are independent of Abeta oligomeric form. Biochemistry 2009, 48, 4388-4402. [CrossRef] [PubMed]

135. Barritt, J.D.; Viles, J.H. Truncated Amyloid- $\beta(11-40 / 42)$ from Alzheimer Disease Binds Cu2+ with a Femtomolar Affinity and Influences Fiber Assembly. J. Bio. Chem. 2015, 290, 27791-27802. [CrossRef]

136. Young, T.R.; Kirchner, A.; Wedd, A.G.; Xiao, Z.G. An integrated study of the affinities of the A beta 16 peptide for Cu(I) and $\mathrm{Cu}(\mathrm{II})$ : Implications for the catalytic production of reactive oxygen species. Metallomics 2014, 6, 505-517. [CrossRef]

137. Chen, W.T.; Liao, Y.H.; Yu, H.M.; Cheng, I.H.; Chen, Y.R. Distinct effects of Zn2+, Cu2+, Fe3+, and Al3+ on amyloid-beta stability, oligomerization, and aggregation: Amyloid-beta destabilization promotes annular protofibril formation. J. Biol. Chem. 2011, 286, 9646-9656. [CrossRef] [PubMed]

138. Schrag, M.; Mueller, C.; Oyoyo, U.; Smith, M.A.; Kirsch, W.M. Iron, zinc and copper in the Alzheimer's disease brain: A quantitative meta-analysis. Some insight on the influence of citation bias on scientific opinion. Prog. Neurobiol. 2011, 94, 296-306. [CrossRef] [PubMed]

139. Atwood, C.S.; Moir, R.D.; Huang, X.; Scarpa, R.C.; Bacarra, N.M.; Romano, D.M.; Hartshorn, M.A.; Tanzi, R.E.; Bush, A.I. Dramatic aggregation of Alzheimer abeta by $\mathrm{Cu}(\mathrm{II})$ is induced by conditions representing physiological acidosis. J. Biol. Chem. 1998, 273, 12817-12826. [CrossRef]

140. Nair, N.G.; Perry, G.; Smith, M.A.; Reddy, V.P. NMR studies of zinc, copper, and iron binding to histidine, the principal metal ion complexing site of amyloid-beta peptide. J. Alzheimers Dis. 2010, 20, 57-66. [CrossRef] [PubMed]

141. Han, D.; Wang, H.; Yang, P. Molecular modeling of zinc and copper binding with Alzheimer's amyloid beta-peptide. Biometals 2008, 21, 189-196. [CrossRef] [PubMed]

142. Pedersen, J.T.; Teilum, K.; Heegaard, N.H.; Østergaard, J.; Adolph, H.W.; Hemmingsen, L. Rapid formation of a preoligomeric peptide-metal-peptide complex following copper (II) binding to amyloid $\beta$ peptides. Angew. Chem. Int. Ed. Engl. 2011, 50, 2532-2535. [CrossRef] [PubMed] 
143. Lin, R.; Chen, X.; Li, W.; Han, Y.; Liu, P.; Pi, R. Exposure to metal ions regulates mRNA levels of APP and BACE1 in PC12 cells: Blockage by curcumin. Neurosci. Let. 2008, 440, 344-347. [CrossRef]

144. Wang, Z.; Zhang, Y.H.; Zhang, W.; Gao, H.L.; Zhong, M.L.; Huang, T.T.; Guo, R.F.; Liu, N.N.; Li, D.D.; Li, Y. Copper chelators promote nonamyloidogenic processing of $\mathrm{A} \beta \mathrm{PP}$ via $\mathrm{MT}_{1 / 2} / \mathrm{CREB}$-dependent signaling pathways in $\mathrm{A} \beta \mathrm{PP} / \mathrm{PS} 1$ transgenic mice. J. Pineal Res. 2018, 65, e12502. [CrossRef]

145. D'Ambrosi, N.; Rossi, L. Copper at synapse: Release, binding and modulation of neurotransmission. Neurochem. Int. 2015, 90, 36-45. [CrossRef] [PubMed]

146. Gaier, E.D.; Eipper, B.A.; Mains, R.E. Copper signaling in the mammalian nervous system: Synaptic effects. J. Neurosci. Res. 2013, 91, 2-19. [CrossRef] [PubMed]

147. Nam, E.; Nam, G.; Lim, M.H. Synaptic Copper, Amyloid- $\beta$, and Neurotransmitters in Alzheimer's Disease. Biochemistry 2020, 59, 15-17. [CrossRef]

148. Dodani, S.C.; Domaille, D.W.; Nam, C.I.; Miller, E.W.; Finney, L.A.; Vogt, S. Calcium-dependent copper redistributions in neuronal cells revealed by a fluorescent copper sensor and X-ray fluorescence microscopy. Proc. Natl. Acad. Sci. USA 2011, 108, 5980-5985. [CrossRef] [PubMed]

149. Thorpe, S.R.; Baynes, J.W. Role of the Maillard reaction in diabetes mellitus and diseases of aging. Drugs Aging 1996, 9, 69-77. [CrossRef] [PubMed]

150. Price, D.L.; Rhett, P.M.; Thorpe, S.R.; Baynes, J.W. Chelating activity of advanced glycation end-product inhibitors. J. Biol. Chem. 2001, 276, 48967-48972. [CrossRef] [PubMed]

151. Munch, G.; Thome, J.; Foley, P.; Schinzel, R.; Riederer, P. Advanced glycation endproducts in ageing and Alzheimer's disease. Brain Res. Rev. 1997, 23, 134-143. [CrossRef]

152. Queisser, M.A.; Yao, D.; Geisler, S.; Hammes, H.P.; Lochnit, G.; Schleicher, E.D.; Brownlee, M.; Preissner, K.T. Hyperglycemia impairs proteasome function by methylglyoxal. Diabetes 2010, 59, 670-678. [CrossRef] [PubMed]

153. Fica-Contreras, S.M.; Shuster, S.O.; Durfee, N.D.; Bowe, G.J.K.; Henning, N.J.; Hill, S.A.; Vrla, G.D.; Stillman, D.R.; Suralik, K.M.; Sandwick, R.K.; et al. Glycation of Lys-16 and Arg-5 in amyloid-beta and the presence of $\mathrm{Cu}(2+)$ play a major role in the oxidative stress mechanism of Alzheimer's disease. J. Biol. Inorg. Chem. 2017, 22, 1211-1222. [CrossRef]

154. Takuma, K.; Fang, F.; Zhang, W.; Yan, S.; Fukuzaki, E.; Du, H.; Sosunov, A.; McKhann, G.; Funatsu, Y.; Nakamichi, N.; et al. RAGE-mediated signaling contributes to intraneuronal transport of amyloid-beta and neuronal dysfunction. Proc. Natl. Acad. Sci. USA 2009, 106, 20021-20026. [CrossRef]

155. Yan, S.D.; Chen, X.; Fu, J.; Chen, M.; Zhu, H.; Roher, A.; Slattery, T.; Zhao, L.; Nagashima, M.; Morser, J.; et al. RAGE and amyloid-beta peptide neurotoxicity in Alzheimer's disease. Nature 1996, 382, 685-691. [CrossRef]

156. Du Yan, S.; Zhu, H.; Fu, J.; Yan, S.F.; Roher, A.; Tourtellotte, W.W.; Rajavashisth, T.; Chen, X.; Godman, G.C.; Stern, D.; et al. Amyloid-beta peptide-receptor for advanced glycation endproduct interaction elicits neuronal expression of macrophage-colony stimulating factor: A proinflammatory pathway in Alzheimer disease. Proc. Natl. Acad. Sci. USA 1997, 94, 5296-5301. [CrossRef]

157. Hadding, A.; Kaltschmidt, B.; Kaltschmidt, C. Overexpression of receptor of advanced glycation end products hypersensitizes cells for amyloid beta peptide-induced cell death. Biochim. Biophys. Acta 2004, 1691, 67-72. [CrossRef]

158. Fang, F.; Lue, L.F.; Yan, S.; Xu, H.; Luddy, J.S.; Chen, D.; Walker, D.G.; Stern, D.M.; Yan, S.; Schmidt, A.M.; et al. RAGE-dependent signaling in microglia contributes to neuroinflammation, Abeta accumulation, and impaired learning/memory in a mouse model of Alzheimer's disease. FASEB J. 2010, 24, 1043-1055. [CrossRef] [PubMed]

159. Westerman, M.A.; Cooper-Blacketer, D.; Mariash, A.; Kotilinek, L.; Kawarabayashi, T.; Younkin, L.H.; Carlson, G.A.; Younkin, S.G.; Ashe, K.H. The relationship between Abeta and memory in the Tg2576 mouse model of Alzheimer's disease. J. Neurosci. 2002, 22, 1858-1867. [CrossRef]

160. Bishop, G.M.; Dang, T.N.; Dringen, R.; Robinson, S.R. Accumulation of non-transferrin-bound iron by neurons, astrocytes and microglia. Neurotox. Res. 2011, 19, 443-451. [CrossRef]

161. Zheng, Z.; White, C.; Lee, J.; Peterson, T.S.; Bush, A.I.; Sun, G.Y.; Weisman, G.A.; Petris, M.J. Altered microglial copper homeostasis in a mouse model of Alzheimer's disease. J. Neurochem. 2010, 114, 1630-1638. [CrossRef]

162. Morales, I.; Sanchez, A.; Rodriguez-Sabate, C.; Rodriguez, M. Striatal astrocytes engulf dopaminergic debris in Parkinson's disease: A study in an animal model. PLoS ONE 2017, 12, e0185989. [CrossRef] [PubMed]

163. Hu, Z.; Yu, F.; Gong, P.; Qiu, Y.; Zhou, W.; Cui, Y.; Li, J.; Chen, H. Subneurotoxic copper(II)-induced NF-kB-dependent microglial activation is associated with mitochondrial ROS. Toxicol. Appl. Pharmacol. 2014, 276, 95-103. [CrossRef] [PubMed]

164. Kitazawa, M.; Hsu, H.W.; Medeiros, R. Copper Exposure Perturbs Brain Inflammatory Responses and Impairs Clearance of Amyloid-Beta. Toxicol. Sci. 2016, 152, 194-204. [CrossRef]

165. Storck, S.E.; Meister, S.; Nahrath, J.; Meißner, J.N.; Schubert, N.; Di Spiezio, A.; Baches, S.; Vandenbroucke, R.E.; Bouter, Y.; Prikulis, I.; et al. Endothelial LRP1 transports amyloid- $\beta(1-42)$ across the blood-brain barrier. J. Clin. Investig. 2016, 126, 123-136. [CrossRef]

166. Lu, J.; Wu, D.M.; Zheng, Y.L.; Sun, D.X.; Hu, B.; Shan, Q.; Zhang, Z.F.; Fan, S.H. Trace amounts of copper exacerbate beta amyloid-induced neurotoxicity in the cholesterol-fed mice through TNF-mediated inflammatory pathway. Brain Behav. Immun. 2009, 23, 193-203. [CrossRef] 
167. Venneti, S.; Lopresti, B.J.; Wang, G.; Hamilton, R.L.; Mathis, C.A.; Klunk, W.E.; Apte, U.M.; Wiley, C.A. PK11195 labels activated microglia in Alzheimer's disease and in vivo in a mouse model using PET. Neurobiol. Aging 2009, 30, 1217-1226. [CrossRef] [PubMed]

168. Yu, F.; Gong, P.; Hu, Z.; Qiu, Y.; Cui, Y.; Gao, X.; Chen, H.; Li, J. Cu(II) enhances the effect of Alzheimer's amyloid- $\beta$ peptide on microglial activation. J. Neuroinflamm. 2015, 12, 122. [CrossRef]

169. Lim, S.L.; Rodriguez-Ortiz, C.J.; Hsu, H.W.; Wu, J.; Zumkehr, J.; Kilian, J.; Vidal, J.; Ayata, P.; Kitazawa, M. Chronic copper exposure directs microglia towards degenerative expression signatures in wild-type and J20 mouse model of Alzheimer's disease. J. Trace Elem. Med. Biol. 2020, 62, 126578. [CrossRef]

170. Tan, X.; Guan, H.; Yang, Y.; Luo, S.; Hou, L.; Chen, H.; Li, J. Cu(II) disrupts autophagy-mediated lysosomal degradation of oligomeric A $\beta$ in microglia via mTOR-TFEB pathway. Toxicol. Appl. Pharmacol. 2020, 401, 115090. [CrossRef] [PubMed]

171. Ashraf, A.; Michaelides, C.; Walker, T.A.; Ekonomou, A.; Suessmilch, M.; Sriskanthanathan, A.; Abraha, S.; Parkes, A.; Parkes, H.G.; Geraki, K.; et al. Regional Distributions of Iron, Copper and Zinc and Their Relationships with Glia in a Normal Aging Mouse Model. Front. Aging Neurosci. 2019, 11, 351. [CrossRef] [PubMed]

172. Lee, K.H.; Yun, S.J.; Nam, K.N.; Gho, Y.S.; Lee, E.H. Activation of microglial cells by ceruloplasmin. Brain Res. 2007, 1171, 1-8. [CrossRef] [PubMed]

173. Bonda, D.J.; Lee, H.G.; Blair, J.A.; Zhu, X.; Perry, G.; Smith, M.A. Role of metal dyshomeostasis in Alzheimer's disease. Metallomics 2011, 3, 267-270. [CrossRef] [PubMed]

174. Acevedo, K.M.; Hung, Y.H.; Dalziel, A.H.; Li, Q.X.; Laughton, K.; Wikhe, K.; Rembach, A.; Roberts, B.; Masters, C.L.; Bush, A.I.; et al. Copper promotes the trafficking of the amyloid precursor protein. J. Biol. Chem. 2011, 286, 8252-8262. [CrossRef]

175. Zucconi, G.G.; Cipriani, S.; Scattoni, R.; Balgkouranidou, I.; Hawkins, D.P.; Ragnarsdottir, K.V. Copper deficiency elicits glial and neuronal response typical of neurodegenerative disorders. Neuropathol. Appl. Neurobiol. 2007, 33, 212-225. [CrossRef]

176. Rossi-George, A.; Guo, C.J.; Oakes, B.L.; Gow, A.J. Copper modulates the phenotypic response of activated BV2 microglia through the release of nitric oxide. Nitric Oxide 2012, 27, 201-209. [CrossRef] [PubMed]

177. Rossi-George, A.; Guo, C.J. Copper disrupts S-nitrosothiol signaling in activated BV2 microglia. Neurochem. Int. 2016, 99, 1-8. [CrossRef] [PubMed]

178. Du, X.; Wang, Z.; Zheng, Y.; Li, H.; Ni, J.; Liu, Q. Inhibitory effect of selenoprotein $\mathrm{P}$ on $\mathrm{Cu}(+) / \mathrm{Cu}(2+)$-induced $\mathrm{A} \beta 42$ aggregation and toxicity. Inorg. Chem. 2014, 53, 1672-1678. [CrossRef] [PubMed]

179. Goch, W.; Bal, W. Numerical Simulations Reveal Randomness of Cu(II) Induced A $\beta$ Peptide Dimerization under Conditions Present in Glutamatergic Synapses. PLoS ONE 2017, 12, e0170749. [CrossRef] [PubMed]

180. Parpura, V.; Heneka, M.T.; Montana, V.; Oliet, S.H.; Schousboe, A.; Haydon, P.G.; Stout, R.F., Jr.; Spray, D.C.; Reichenbach, A.; Pannicke, T.; et al. Glial cells in (patho)physiology. J. Neurochem. 2012, 121, 4-27. [CrossRef]

181. Tiffany-Castiglioni, E.; Hong, S.; Qian, Y. Copper handling by astrocytes: Insights into neurodegenerative diseases. Int. J. Dev. Neurosci. 2011, 29, 811-818. [CrossRef]

182. Scheiber, I.F.; Dringen, R. Astrocyte functions in the copper homeostasis of the brain. Neurochem. Int. 2013, 62, 556-565. [CrossRef] [PubMed]

183. Brown, D.R. Role of the prion protein in copper turnover in astrocytes. Neurobiol. Dis. 2004, 15, 534-543. [CrossRef] [PubMed]

184. Scheiber, I.F.; Mercer, J.F.; Dringen, R. Copper accumulation by cultured astrocytes. Neurochem. Int. 2010, 56, 451-460. [CrossRef]

185. Scheiber, I.F.; Schmidt, M.M.; Dringen, R. Copper export from cultured astrocytes. Neurochem. Int. 2012, 60, 292-300. [CrossRef]

186. Qian, Y.; Zheng, Y.; Taylor, R.; Tiffany-Castiglioni, E. Involvement of the molecular chaperone Hspa5 in copper homeostasis in astrocytes. Brain Res. 2012, 1447, 9-19. [CrossRef]

187. Reddy, P.V.; Rao, K.V.; Norenberg, M.D. The mitochondrial permeability transition, and oxidative and nitrosative stress in the mechanism of copper toxicity in cultured neurons and astrocytes. Lab. Investig. 2008, 88, 816-830. [CrossRef]

188. Chen, S.H.; Lin, J.K.; Liu, S.H.; Liang, Y.C.; Lin-Shiau, S.Y. Apoptosis of cultured astrocytes induced by the copper and neocuproine complex through oxidative stress and JNK activation. Toxicol. Sci. 2008, 102, 138-149. [CrossRef] [PubMed]

189. Witt, B.; Stiboller, M.; Raschke, S.; Friese, S.; Ebert, F.; Schwerdtle, T. Characterizing effects of excess copper levels in a human astrocytic cell line with focus on oxidative stress markers. J. Trace Elem. Med. Biol. 2021, 65, 126711. [CrossRef]

190. Scheiber, I.F.; Dringen, R. Copper-treatment increases the cellular GSH content and accelerates GSH export from cultured rat astrocytes. Neurosci. Lett. 2011, 498, 42-46. [CrossRef]

191. Pal, A.; Badyal, R.K.; Vasishta, R.K.; Attri, S.V.; Thapa, B.R.; Prasad, R. Biochemical, histological, and memory impairment effects of chronic copper toxicity: A model for non-Wilsonian brain copper toxicosis in Wistar rat. Biol. Trace Elem. Res. 2013, 153, 257-268. [CrossRef] [PubMed]

192. Pal, A.; Vasishta, R.k.; Prasad, R. Hepatic and hippocampus iron status is not altered in response to increased serum ceruloplasmin and serum "free" copper in Wistar rat model for non-Wilsonian brain copper toxicosis. Biol. Trace Elem. Res. 2013, 154, 403-411. [CrossRef]

193. White, A.R.; Multhaup, G.; Maher, F.; Bellingham, S.; Camakaris, J.; Zheng, H.; Bush, A.I.; Beyreuther, K.; Masters, C.L.; Cappai, R. The Alzheimer's disease amyloid precursor protein modulates copper-induced toxicity and oxidative stress in primary neuronal cultures. J. Neurosci. 1999, 19, 9170-9179. [CrossRef] [PubMed]

194. Ferretti, G.; Bacchetti, T.; Moroni, C.; Vignini, A.; Curatola, G. Copper-induced oxidative damage on astrocytes: Protective effect exerted by human high density lipoproteins. Biochim. Biophys. Acta 2003, 1635, 48-54. [CrossRef] 
195. Currais, A.; Maher, P. Functional consequences of age-dependent changes in glutathione status in the brain. Antioxid. Redox Signal 2013, 19, 813-822. [CrossRef]

196. Squitti, R.; Barbati, G.; Rossi, L.; Ventriglia, M.; Dal Forno, G.; Cesaretti, S.; Moffa, F.; Caridi, I.; Cassetta, E.; Pasqualetti, P.; et al. Excess of nonceruloplasmin serum copper in AD correlates with MMSE, CSF [beta]-amyloid, and h-tau. Neurology 2006, 67, 76-82. [CrossRef]

197. Dirnagl, U.; Simon, R.P.; Hallenbeck, J.M. Ischemic tolerance and endogenous neuroprotection. Trends Neurosci. 2003, 26, 248-254. [CrossRef]

198. Folstein, M.F.; Folstein, S.E.; McHugh, P.R. “Mini-mental state". A practical method for grading the cognitive state of patients for the clinician. J. Psychiatr. Res. 1975, 12, 189-198. [CrossRef]

199. Mathys, Z.K.; White, A.R. Copper and Alzheimer's Disease. Adv. Neurobiol. 2017, 18, 199-216. [CrossRef]

200. Garwood, C.J.; Ratcliffe, L.E.; Simpson, J.E.; Heath, P.R.; Ince, P.G.; Wharton, S.B. Astrocytes in Alzheimer's disease and other age-associated dementias: A supporting player with a central role. Neuropathol. Appl. Neurobiol. 2017, 43, 281-298. [CrossRef]

201. Sama, M.A.; Mathis, D.M.; Furman, J.L.; Abdul, H.M.; Artiushin, I.A.; Kraner, S.D.; Norris, C.M. Interleukin-1beta-dependent signaling between astrocytes and neurons depends critically on astrocytic calcineurin/NFAT activity. J. Biol. Chem. 2008, 283, 21953-21964. [CrossRef]

202. Vincent, A.J.; Gasperini, R.; Foa, L.; Small, D.H. Astrocytes in Alzheimer's disease: Emerging roles in calcium dysregulation and synaptic plasticity. J. Alzheimers Dis. 2010, 22, 699-714. [CrossRef] [PubMed]

203. Pike, C.J.; Cummings, B.J.; Monzavi, R.; Cotman, C.W. Beta-amyloid-induced changes in cultured astrocytes parallel reactive astrocytosis associated with senile plaques in Alzheimer's disease. Neuroscience 1994, 63, 517-531. [CrossRef]

204. Bierhaus, A.; Stern, D.M.; Nawroth, P.P. RAGE in inflammation: A new therapeutic target? Curr. Opin. Investig. Drugs 2006, 7, 985-991.

205. Masters, S.L.; O'Neill, L.A. Disease-associated amyloid and misfolded protein aggregates activate the inflammasome. Trends Mol. Med. 2011, 17, 276-282. [CrossRef]

206. Johnstone, M.; Gearing, A.J.; Miller, K.M. A central role for astrocytes in the inflammatory response to beta-amyloid; chemokines, cytokines and reactive oxygen species are produced. J. Neuroimmunol. 1999, 93, 182-193. [CrossRef]

207. Forloni, G.; Mangiarotti, F.; Angeretti, N.; Lucca, E.; De Simoni, M.G. Beta-amyloid fragment potentiates IL-6 and TNF-alpha secretion by LPS in astrocytes but not in microglia. Cytokine 1997, 9, 759-762. [CrossRef] [PubMed]

208. Hu, J.; Akama, K.T.; Krafft, G.A.; Chromy, B.A.; Van Eldik, L.J. Amyloid-beta peptide activates cultured astrocytes: Morphological alterations, cytokine induction and nitric oxide release. Brain Res. 1998, 785, 195-206. [CrossRef]

209. Chen, S.H.; Liu, S.H.; Liang, Y.C.; Lin, J.K.; Lin-Shiau, S.Y. Death signaling pathway induced by pyrrolidine dithiocarbamate$\mathrm{Cu}(2+)$ complex in the cultured rat cortical astrocytes. Glia 2000, 31, 249-261. [CrossRef]

210. Griffin, W.S.; Sheng, J.G.; Royston, M.C.; Gentleman, S.M.; McKenzie, J.E.; Graham, D.I.; Roberts, G.W.; Mrak, R.E. Glial-neuronal interactions in Alzheimer's disease: The potential role of a 'cytokine cycle' in disease progression. Brain Pathol. 1998, 8, 65-72. [CrossRef]

211. Arancio, O.; Zhang, H.P.; Chen, X.; Lin, C.; Trinchese, F.; Puzzo, D.; Liu, S.; Hegde, A.; Yan, S.F.; Stern, A.; et al. RAGE potentiates Abeta-induced perturbation of neuronal function in transgenic mice. EMBO J. 2004, 23, 4096-4105. [CrossRef] [PubMed]

212. Askarova, S.; Yang, X.; Sheng, W.; Sun, G.Y.; Lee, J.C. Role of A $\beta$-receptor for advanced glycation end products interaction in oxidative stress and cytosolic phospholipase $\mathrm{A}_{2}$ activation in astrocytes and cerebral endothelial cells. Neuroscience 2011, 199, 375-385. [CrossRef] [PubMed]

213. Shaffer, L.M.; Dority, M.D.; Gupta-Bansal, R.; Frederickson, R.C.; Younkin, S.G.; Brunden, K.R. Amyloid beta protein (A beta) removal by neuroglial cells in culture. Neurobiol. Aging 1995, 16, 737-745. [CrossRef]

214. DeWitt, D.A.; Perry, G.; Cohen, M.; Doller, C.; Silver, J. Astrocytes regulate microglial phagocytosis of senile plaque cores of Alzheimer's disease. Exp. Neurol. 1998, 149, 329-340. [CrossRef] [PubMed]

215. Choo, X.Y.; Liddell, J.R.; Huuskonen, M.T.; Grubman, A.; Moujalled, D.; Roberts, J.; Kysenius, K.; Patten, L.; Quek, H.; Oikari, L.E.; et al. Cu ${ }^{\mathrm{II}}$ (atsm) Attenuates Neuroinflammation. Front. Neurosci. 2018, 12, 668. [CrossRef] [PubMed]

216. Matyash, V.; Kettenmann, H. Heterogeneity in astrocyte morphology and physiology. Brain Res. Rev. 2010, 63, 2-10. [CrossRef] [PubMed] 